Article

\title{
Biocontrol Potential of Purified Elicitor Protein PeBL1 Extracted from Brevibacillus laterosporus Strain A60 and Its Capacity in the Induction of Defense Process against Cucumber Aphid (Myzus persicae) in Cucumber (Cucumis sativus)
}

\author{
Khadija Javed ${ }^{1}$, , Humayun Javed ${ }^{2}$ and Dewen Qiu ${ }^{1, *}$ \\ 1 State Key Laboratory for Biology of Plant Diseases and Insect Pests, Institute of Plant Protection, \\ Chinese Academy of Agricultural Sciences, No. 12 Zhong-Guan-Cun South Street, Beijing 100081, China; \\ khadijajaved829@gmail.com or 2017Y90100105@caas.cn \\ 2 Department of Entomology, Pir Mehr Ali Shah Arid Agriculture University, Rawalpindi 46000, Pakistan; \\ hjhumayun@gmail.com \\ * Correspondence: Qiudewen@caas.cn
}

Received: 1 June 2020; Accepted: 14 July 2020; Published: 21 July 2020

check for updates

\begin{abstract}
The Cucumber aphid (Myzus persicae), a destructive cucumber aphid usually managed by chemical pesticides, is responsible for enormous annual agricultural losses. A protein elicitor, PeBL1, was investigated in the present work for its ability to induce a defense response against M. persicae in cucumber. The rates of population growth (Intrinsic rate of increase) of M. persicae (second and third generations) decreased with PeBL1-treated cucumber seedlings as compared to positive (water) and negative $70.58 \mu \mathrm{g} \mathrm{mL}^{-1}$ controls (50 mM Tris- $\mathrm{HCl}, \mathrm{pH} \mathrm{8.0).} \mathrm{In} \mathrm{an} \mathrm{assay}$ on host selection, M. persicae had a preference for colonizing control plants as compared to the PeBL1-treated cucumber seedlings. The nymphal development time of the aphid was extended with the PeBL1-treated cucumber seedlings. Likewise, fecundity was reduced, with less offspring produced in the PeBL1-treated cucumber seedlings as compared to the positive (water) and negative $70.58 \mu \mathrm{g} \mathrm{mL}{ }^{-1}$ controls (50 mM Tris- $\mathrm{HCl}, \mathrm{pH}$ 8.0). The cucumber leaves treated with PeBL1 had a hazardous surface environment for M. persicae, caused by trichomes and wax formation. Jasmonic acid (JA), salicylic acid (SA), and ethylene (ET) levels were significantly higher, exhibiting significant accumulation in the PeBL1-treated cucumber seedlings. The following results showed that PeBL1 considerably altered the height of the cucumber plant and the surface structure of the leaves to minimize M. persicae reproduction, and it prevented colonization. Defensive processes also included the activation of pathways (JA, SA, and ET). This study provides evidence of biocontrol for the use of PeBL1 in cucumber defense against $M$. persicae.
\end{abstract}

Keywords: PeBL1; Myzus persicae; aphid resistance; electrical penetration graph; defense pathways; jasmonic acid; salicylic acid; ethylene

\section{Introduction}

A multifaceted relationship has been established between herbivores and plants during development. Plants damaged by herbivores show the accumulation of toxic or volatile organic compounds with the modification of their physical structures. The structures and compounds affect the growth, colonization, feeding, survival, and oviposition of herbivores, and they attract natural enemies and encourage them to induce defense [1]. In order to deal effectively with this damage, two mainly constitutive defense mechanisms have been developed by plants [2]. Plants are prevented from 
colonizing by physically impaired barriers, including cuticle trichomes, callose, cell walls, and suberin, while antibiotic allelochemicals affect or induce pest production, fertility, and insect durability [3]. Aphids are phloem-feeding insects that spread plant viruses through the ingestion of plant sap, resulting in severe crop losses $[4,5]$. In various aphid-plant systems, defense responses caused by aphids have been studied. Arabidopsis thaliana was shown to be less viable in green peach aphids in infested leaves [6]. In chili plants, dietary effects were induced and volatile organic compounds were released with a repellent outcome versus infested Bemisia tabaci [7]. In Brassica napus, there was a decrease in survival rate and population growth parameters of immature Plutella xylostella due to Brevicoryne brassicae resistance [8].

The defense response in plants is induced by jasmonic acid (JA), salicylic acid (SA), and ethylene (ET) [9]. SA has been found to be involved in the defense against sucking-piercing insects, while JA has been found against chewing insects [10]. ET controls different processes associated with plant defense responses [11]. Danaus plexippus increases JA pathway activation but controls acquisition in SA in the case of the oleander aphids, Aphis nerii; JA caused the opposite impact in Asclepias syriaca [11]. Few previous studies have demonstrated the involvement of JA and SA in the induction of aphid response from enhanced expressions of genes like PR-1, PR-2, CHIT1, LOX1, and PAL that have been identified as responses induced by JA-SA, after aphid feeding [12,13].

Because of its feeding behavior, Myzus persicae, a major destructive pest of cucumber, maize, barley, wheat, and beans in China, has a direct impact on the yield and quality of the crops. Biotic and abiotic elicitors are the catalyst for plant defense response [14]. Different pathogens, including fungi, bacteria, viruses, and oomycetes, are associated with the elicitors. Proteins, glycoproteins, peptides, lipids, and oligosaccharides are the most common elicitors [15]. They comprise two main groups-race-specific groups that trigger a defense response only for host plants and those that lead to a general defense response for both host and non-host plants [16]. Due to the increased demand for food safety, quality elicitors have been studied as replacements for certain chemical pesticides [17-20].

PeBL1 is a broad spectrum, widely-specific elicitor studied in the A60 strain of Brevibacillus laterosporus and has been found to be able to activate resistance in plants through the JA and SA pathways. It triggers defense enzyme activation, strengthens cell walls, and increases the regulation of other defense-associated genes [21]. The pathogenicity of B. laterosporus is associated with and active against dipteran flies and mosquitoes, and it is related to a mixture of sporulated cultures with or without parasporal bodies [22]. A typical, morphologically marked spore surrounded by a strongly attached canoe-shaped parasporal body is the B. laterosporus anti-microbial species, and it is a pathogen of invertebrates. The potential for biocontrol in B. laterosporus includes not only phytopathogenic fungi and bacteria but also insects, nematodes, and mollusks [22]. The biocontrol potentials of insects in the orders of Coleoptera, Lepidoptera, and Diptera have been studied in entomopathogenic species [23]. Applications of the PeBL1 elicitor on cucumber seedlings were studied in the current study, as were the function and mechanism of the effects of PeBL1 on cucumber aphid control to assess the potential impact of PeBL1 on M. persicae. Trichomes were found in leaf the surface structure, and so the contents of JA and SA gene expression from JA and SA were carried out. Data on PeBL1's function, mechanism, and effects in the control of cucumber aphid are herein provided.

\section{Materials and Methods}

\subsection{Aphid and Plant Preparation}

Myzus persicae (Sulzer), commonly known as the green peach aphid, was collected from the cucumber field at the Chinese Academy of Agricultural Sciences in Beijing, China, and transferred to cucumber seedlings (Cucumis sativus). The aphid was reared in a chamber with 16:8 h light/dark photoperiod, $60 \%$ relative humidity $(\mathrm{RH})$, and $23 \pm 1{ }^{\circ} \mathrm{C}$ at the State Key Laboratory for Biology of Plant Diseases and Insect Pests, Institute of Plant Protection, Chinese Academy of Agricultural Sciences, No. 12 Zhong-Guan-Cun South Street, Beijing 100081, China. Cucumber (C. sativus) seeds 
were sterilized with $75 \%$ ethanol over 15-20 s and washed with distilled water, and then they were pre-soaked in distilled water $2-3$ days before use.

\subsection{Evaluation of PeBL1}

PeBL1 was produced with the recombinant vector pET30-TEV/LIC in Escherichia coli BL21-DE3 (Novagen, Darmstadt, Germany). The pellets were removed, and the supernatant cells were resuspended and sonified by the ultrasonic disruptor. The supernatant was collected and filtered with filter paper (size $0.22 \mu \mathrm{m}$ ) after the solution was centrifuged at 12,000 rpm for $15 \mathrm{~min}$. The Äkta Explorer Protein Purification System (Amersham Biosciences, Temecula, CA, USA), as described by Wang et al. [21], with a His-Trap HP column (GE Healthcare, Waukesha, WI, USA), used various loading buffers (A, B, C, and D) for the further purification of the elicitor protein PeBL1. Buffer A (50 Mm Tris- $\mathrm{HCl}, 8.0 \mathrm{pH}$ ), washed off other elicitors from the column quickly, and buffer B was used to stabilize the column ( $50 \mathrm{Mm}$ Tris- $\mathrm{HCl}, 200 \mathrm{Mm} \mathrm{NaCl})$. For the solution elution elicitor protein, Buffer C (50 Mm Tris- $\mathrm{HCl}, 200 \mathrm{Mm} \mathrm{NaCl}$, and $20 \mathrm{Mm}$ imidazole, $\mathrm{pH}$ 8.0), and elusion Buffer D (50 Mm Tris- $\mathrm{HCl}, 200 \mathrm{Mm} \mathrm{NaCl}$, and $500 \mathrm{Mm}$ imidazole, $\mathrm{pH}$ 8.0). Then the PeBL1 elicitor protein was desalted in a HiTrap desalting column (GE Healthcare, Waukesha, WI, USA), as described by Wang et al. [21]. The molecular mass of the purified elicitor protein was measured by a 12\% SDS-PAGE resolving gel, and a GenStar M223 protein marker $(\sim 5-245 \mathrm{kDa})$ was used for the estimation of the molecular mass of the purified PeBL1 elicitor.

\subsection{The Population of M. persicae}

Cucumber seeds and young seedlings were soaked for $24 \mathrm{~h}$ in four concentrations of the PeBL1 solution, i.e., $70.58,42.34,21.17$, and $17.64 \mu \mathrm{g} \mathrm{mL}{ }^{-1}$. Three seeds in a single pot were cultivated in organic soil (Flora Guard substrate). Three-week-old seedlings of cucumber with the different concentrations of the PeBL1 solution were sprayed after 7 days and then inoculated with 10-12 adults of $M$. persicae per plant after $24 \mathrm{~h}$. For M. persicae, after inoculation, the number of settled aphids' population, was recorded after every 5 days as described by Li et al. [24]. Water and $70.58 \mu \mathrm{g} \mathrm{mL}^{-1}$ of a buffer ( $50 \mathrm{mM}$ Tris- $\mathrm{HCl}, \mathrm{pH} 8.0$ ) were tested for positive and negative controls. A CRD randomized statistical design was used. Transparent air-permeable cages were used to separate seedlings from each plant. The experiment was conducted twice with four replications.

\subsection{The Intrinsic Rate of Increase of M. persicae}

Cucumber seeds were soaked in $70.58 \mu \mathrm{g} \mathrm{mL} \mathrm{m}^{-1}$ of a purified protein solution for $24 \mathrm{~h}$ and then transferred for sprouting 2-3 days in distilled water in petri plates. A CRD randomized statistical design was used. Seedlings were sprayed after $24 \mathrm{~h}$ with $70.58 \mu \mathrm{g} \mathrm{mL} \mathrm{m}^{-1}$ of the PeBL1 purified protein solution. Inoculation with a freshly born M. persicae nymph was then carried out for every seedling. A glass tube cotton-gauze was used to separate all seedlings. Twice a day, the new-born aphid was observed to record the total time and number of offspring produced, which were removed every day. The same test was conducted on seeds and seedlings after 5 days. The experiment was repeated twice individually, with 30 replicates per treatment. The increase in each aphid's intrinsic rate was measured by:

$$
r m=0.738 \times(\ln M d) / T d .
$$

$M d$ is the number of nymph's new-born in the development time equal to $T_{d}$, which is the time between an aphid's birth and its first reproduction

\subsection{Feeding Preference of M. persicae Choice Test}

Cucumber seeds and seedlings, as described in Section 2.2, were treated. The cucumber PeBL1-treated and control seedlings were put in a transparent breathable cage $(60 \times 60 \times 60) \mathrm{cm}$ with cross-touch leaves and a white cardboard bridge $(12 \times 4) \mathrm{cm}$ connecting the base section of stems. 
A CRD randomized statistical design was used. Thirty wingless $M$. persicae adults in the center of the bridge were released. The experiment was repeated 15 times, and after $24 \mathrm{~h}$, the aphids were counted on each seedling.

\subsection{Detection of Aphid Feeding Activities by Electrical Penetration Graph (EPG)}

As previously described, the cucumber seeds were soaked and germinated for 3-4 days in distilled water. Similarly, sized seedlings were then individually planted to organic soil until day 7 . Twenty-four hours after the spraying of the seedlings, an electrical penetration graph (EPG; GIGA-8d) was used on wingless, 12-15-day-old, healthy adult $M$. persicae. Before the test, all aphids were starved for $1 \mathrm{~h}$. The experiments were conducted daily for $4 \mathrm{~h}$ at the same time. An A B stylet was used for the determination and manual study of the aphid feeding waves. A wave identifier was previously described [25].

\subsection{Aphid Bioassay}

A bioassay of the PeBL1 elicitor was carried out with different concentrations of the protein purified solution, i.e., $70.58,42.34,21.17$, and $17.64 \mu \mathrm{g} \mathrm{mL}-1$, a positive control (water alone), and a negative control (70.58 $\mu \mathrm{g} \mathrm{mL}^{-1}$ buffer) against $M$. persicae on the plants of cucumber. A Bradford assay was used to determine different protein concentrations. At the three-leaf stage of the cucumber plant, approximately $2-3 \mathrm{~mL}$ of PeBL1 was applied with a separate spray bottle until the solution drained off from plants. For positive and negative controls, waters and buffers ( $50 \mathrm{mM}$ Tris- $\mathrm{HCl}$, $\mathrm{pH}$ 8.0) were used. The plants were allowed to dry overnight, and 3-5 numbers of freshly molted 0-6 $\mathrm{h}$ aphids were allowed to feed on these plants. The time of nymph development was observed by consecutive observations at intervals of $3 \mathrm{~h}$ until the bioassays were completed for each instar as the total number of offspring produced by all aphid instars, while the number of days in which aphids lived was considered the longevity. Data were compared statistically by a factorial ANOVA and least significant difference (LSD) at $\alpha=0.05$. Bioassays were repeated independently at three non-identical temperature regimes $\left(20,24,27^{\circ} \mathrm{C}\right)$ by using 10 replicates per treatment.

\subsection{Effect of PeBL1 on the Growth and Structure of Cucumber}

Seven-day-old cucumber seedlings were treated in the same manner as above. One day after the seedlings were sprayed, the seeds were soaked for eight days. The central part for the first leaves was collected and tested, while $3.5 \%$ glutaraldehyde diluted into a $0.1 \mathrm{M}$ phosphate buffer (pH 7.2) was used for sampling up to $48 \mathrm{~h}$. For approximately $15 \mathrm{~min}$, all samples were cleanly washed in a $0.1 \mathrm{M}$ phosphate buffer ( $\mathrm{pH}$ 7.2) and then submerged in 1 percent osmic acid for about $2 \mathrm{~h}$ five different times. A gradient of ethanol of 100, 95, 90, 80, 70, 60, 50, and 30\% was used for $15 \mathrm{~min}$. A Leica EM critical point dryer (CPD030; Leica Biosystems, Wetzlar, Germany) was used to dry all samples at critical points. A Hitachi H-7650 transmission electron microscope was used to monitor all samples, Total plant height $(\mathrm{cm})$, total chlorophyll amount (SPAD), total fresh and dry weight, and the number of plant leaves, with 10 replicates per treatment, were measured in order to quantify the effect of PeBL1-treated settlements. A CRD randomized statistical design was used, and data were compared statistically by an ANOVA and LSD at $\alpha=0.05$.

\subsection{HPLC/MS Detection of the Plant Hormone}

As before, seeds and seven-day-old seedlings were treated. As mentioned above, approximately $0.5 \mathrm{~g}$ of the aerial part of the seedlings was collected to extract SA, JA, and ET [26]. A high-performing liquid chromatography spectrometer was used to inject some $20 \mu \mathrm{L}$ of extraction (HPLC/MS; Shimazu Research Instruments, ODS-C18, $3 \mu \mathrm{m}, 2.1$ per $150 \mathrm{~mm}$ Kyoto, Japan). HPLC was performed at a flow rate of $0.2 \mathrm{~mL} \mathrm{~min}^{-1}$ with a mobile phase of $60 \%$ methanol, $40{ }^{\circ} \mathrm{C}$ column temperature, and $4{ }^{\circ} \mathrm{C}$ sample temperature. In the negative ion mode (SA m/z: 137.00; JA: 209.05) MS was set at the selected ion monitoring system (SIM) with a solvent temperature of $250{ }^{\circ} \mathrm{C}$, a heat block temperature of $200{ }^{\circ} \mathrm{C}$, 
a drying gas flow rate of $10 \mathrm{~L} \mathrm{~min}^{-1}$, a nebulizing gas flow of $1.5 \mathrm{~L} \mathrm{~min}^{-1}$, a detector voltage of $1.30 \mathrm{kV}$, and an interface voltage of $-3.5 \mathrm{kV}$.

\subsection{Expression of the Gene by Q-RT-PCR}

TransGen Biotech (Beijing, China) kits were used for extracting RNA, synthesizing cDNA, and conducting a quantitative polymerase chain reaction in real-time (RT-qPCR) (ABI 7500 Real-Time PCR System). The excellence of RNA was calculated with an NP80 nano-photometer. The tested JA, SA, and ET genes were ChIT1 (class III chitinases PR-3); $\beta$-1,3-Glucanase (beta-glucanase); PAL1 (phenylalanine ammonia-lyase); LOX1 (lipoxygenase multifunctional proteins), PR1 (pathogenesis-related to protein 1), cupi4 (cucumber pathogenesis-induced 4), and PR2 (pathogenesis-related to protein 2); the ribosomal gene $18 \mathrm{~S}$ was considered as the internal reference gene [27]. The primers of all pathways are listed in Table A1 of Appendix A. The application of the $2^{-\Delta \Delta C T}$ was used to check the relative fold expression of the genes [28].

\subsection{Analysis of Data}

Data from two treatments were compared statistically using an independent Leven's test, and a two-tailed $t$-test and data obtained from three or more treatments were compared statistically by the LSD and an ANOVA. Statistix software version 8.1 (Analytical Software, Tallahassee, FL, USA) was used for statistical data analysis. Data on the fecundity of aphids were square-root transformed prior to analysis. In order to take out differences, a one-way factorial analysis of variance was performed among treatment factors such as the concentrations of PeBL1 elicitor and different temperature regimes, followed by the least significant difference test, at a probability of $95 \%$. The expressions of genes (RT-qPCR) were obtained by the comparative CT $\left(2^{-\Delta \Delta C T}\right)$ method. The Student's $t$-test $(p=0.05)$ was used to compare fold changes in the plant samples treated with the elicitor and the buffer.

\section{Results}

\subsection{Expression, Purification, and Evaluation of PeBL1 Elicitor Protein}

The PET30-TEV/LIC recombinant vector was transformed into E. coli BL21 (DE3) cells. The expressed His6-PeBL1 was soluble in E. coli after successful transformation. PeBL1 was purified with the column of the His-Trap HP (GE Healthcare, Waukesha, WI) (Figure 1A) and was desalted, as previously described by Wang et al. [21], in the HiTrap column. A single band showed the characteristics of pure recombinant protein at $12 \mathrm{kDa}$ on Tricine SDS-PAGE (Figure 1B).

\subsection{Myzus persicae Performance Indoors}

PeBL1 induced resistance to cucumber aphid M. persicae in two separate ways. First, a settled aphid population decrease was observed in the PeBL1-treated cucumber seedlings (Table 1), and the percentage decreases in population count in PeBL1 treatment relative to the buffer and control treatments are indicated in Tables A2-A4 of Appendix B. M. persicae, in the host selection assay, preferred to feed on the control cucumber seedlings. A day after the inoculation of the aphid and two days after spraying of the seedlings, the amount of M. persicae colonizing PeBL1-treated plants was significantly lower than the control and "Elsewhere" - the latter of which is aphid colonization in places other than buffer-and PeBL1-treated areas (Table A5 of Appendix C). Based on their feeding behavior, some aphids showed colonization in areas opposite to that treated with buffer and PeBL1, (Figure 2A,B). Second, in the case of PeBL1 treatment, the developmental time of the cucumber aphid was extended more compared to the control, whereas the everyday reproductive abilities of M. persicae that were fed on seedlings treated with PeBL1 were reduced (second and third nymphal instars). Second and third generations experienced lower growth rates (Table 2). 
A

Positive clones , bacterial Growt
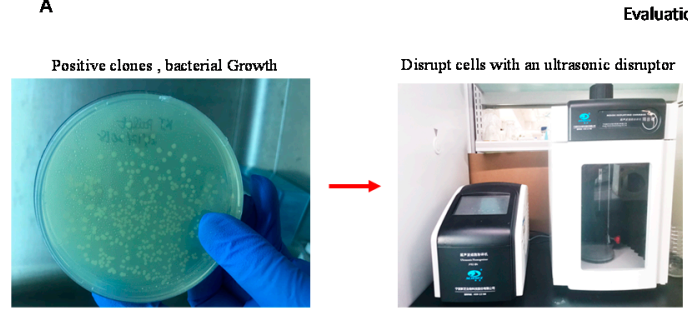

valuation of recombinant protein

uptor
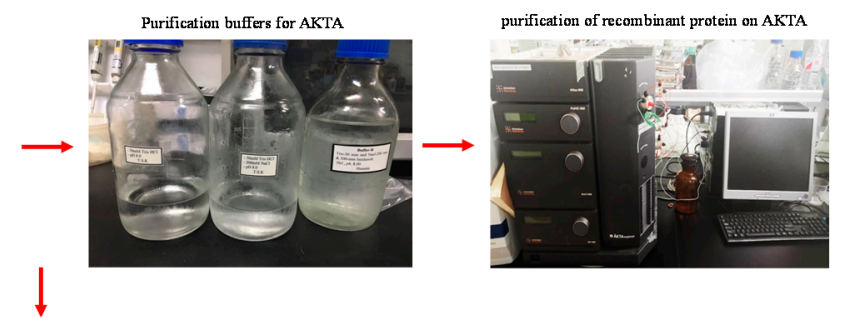

PeBL1 expressed expression (AKTA) with single protein band on SDS gel

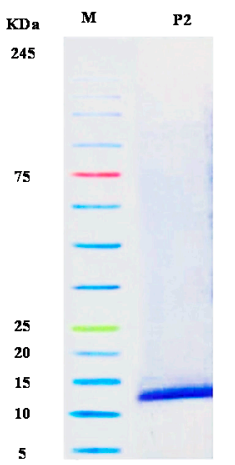

Figure 1. PeBL1 recombinant protein purification. (A) Evaluation of recombinant protein by using the Äkta explorer (B) His-Trap HP column used for the purification of total E. coli proteins. An elution buffer-25 mM Tris, $200 \mathrm{mM} \mathrm{NaCl}, 500 \mathrm{mM}$ imidazole, and pH 8.0-was used to elute peak P2, which comprised recombinant PeBL1 with a flow rate of $5 \mathrm{~mL} / \mathrm{min}$. A HiTrap desalting column was used to load P2. The purified and desalted PeBL1 protein formed a single band of the molecular mass of 12 kDa on Tricine SDS-PAGE. Lane M: protein molecular mass marker; lane P2: peak P2.

Table 1. M. persicae settled population data in PeBL1-treated, control, and buffer-treated cucumber seedlings showed differences of $M$. persicae number after every 5, 10, and 15 days.

\begin{tabular}{cccc}
\hline Days after Aphid Inoculation & Control & Buffer & PeBL1 \\
\hline 5 & $51.99 \pm 0.55 \mathrm{~b}$ & $60.941 \pm 0.28 \mathrm{a}$ & $44.70 \pm 1.19 \mathrm{c}$ \\
10 & $106.39 \pm 1.22 \mathrm{~b}$ & $122.18 \pm 0.91 \mathrm{a}$ & $87.763 \pm 1.98 \mathrm{c}$ \\
15 & $216.70 \pm 0.97 \mathrm{~b}$ & $250.35 \pm 1.07 \mathrm{a}$ & $173.80 \pm 2.01 \mathrm{c}$ \\
\hline
\end{tabular}

Note: Data are shown as mean \pm SD. Data were compared statistically by an ANOVA and LSD in Statistix software, version 8.1. Significant differences can be seen in letters in rows at all treated samples after the inoculation of the aphid on the same day $(p=0.05)$.

Table 2. Developmental time, reproduction capacity, and increase of the intrinsic rate of M. persicae in PeBL1-treated and control seedlings of cucumber.

\begin{tabular}{ccccccc}
\hline \multirow{2}{*}{$\begin{array}{c}\text { Generations of } \\
\text { M. persicae }\end{array}$} & \multicolumn{2}{c}{ Td (Day) } & \multicolumn{2}{c}{ No of Nymphs per Day } & \multicolumn{2}{c}{$\mathbf{r}_{\mathrm{m}}$} \\
\cline { 2 - 7 } & Control & PeBL1 & Control & PeBL1 & Control & PeBL1 \\
\hline 1st & $6.82 \pm 0.31$ & $6.48 \pm 0.19$ & $3.51 \pm 0.06$ & $3.21 \pm 0.09$ & $0.41 \pm 0.01$ & $0.37 \pm 0.02$ \\
2nd & $6.13 \pm 0.28$ & $6.24 \pm 0.22$ & $2.68 \pm 0.10$ & $2.24 \pm 0.12$ & $0.33 \pm 0.01$ & $0.26 \pm 0.01$ * \\
3rd & $6.92 \pm 0.35$ & $6.64 \pm 0.30$ & $1.76 \pm 0.13$ & $1.44 \pm 0.06$ & $0.18 \pm 0.00$ & $0.16 \pm 0.01 *$ \\
\hline
\end{tabular}

Note: Data are shown as mean \pm SD. Td represents development time, Number of nymphs per day represents average reproduction ability, and $r_{m}$ is the increase of intrinsic rate. Data were compared statistically with an ANOVA and LSD in Statistix, version 8.1. Asterisks show difference between PeBL1 and control treatments *; $(p=0.05)$. 
A

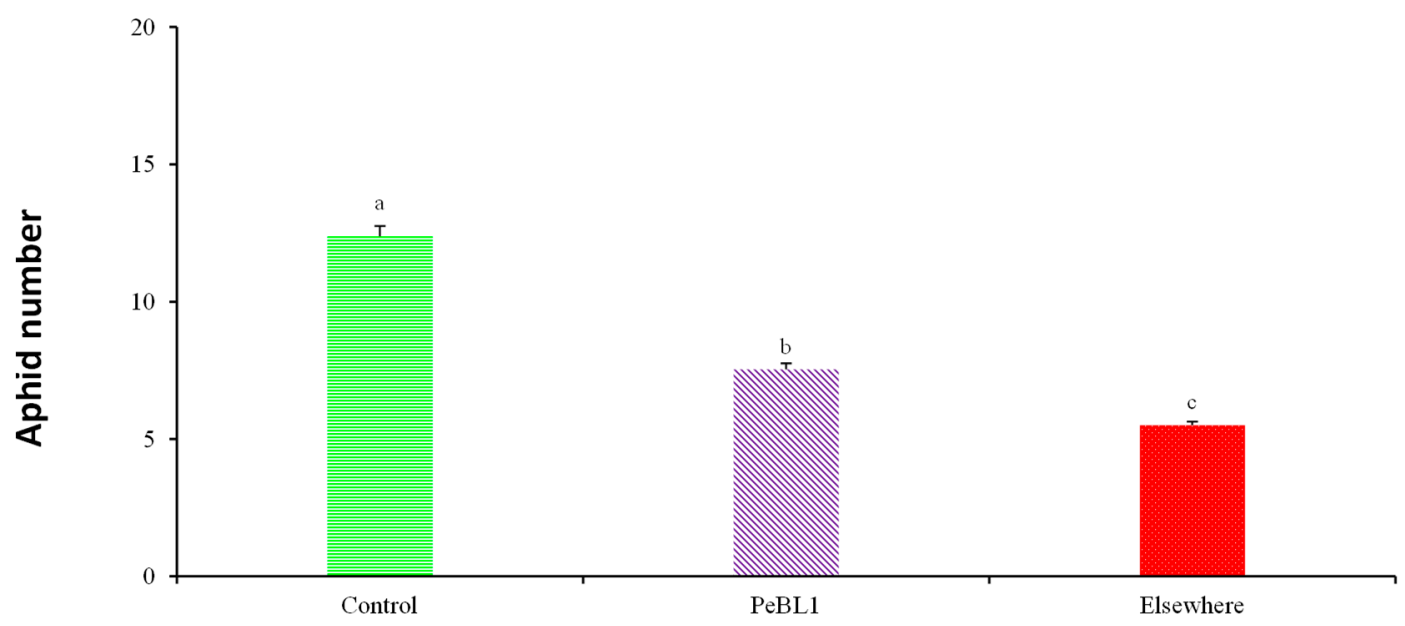

B

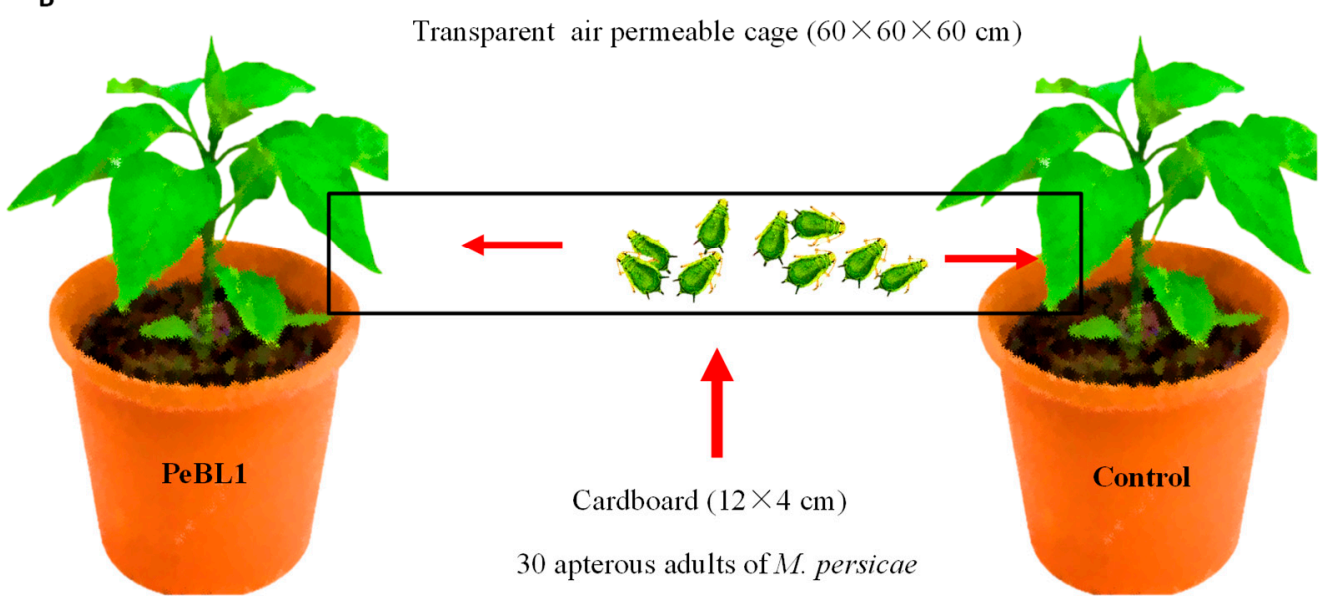

M. persicae preferred feeding on control cucumber seedlings as compared to PeBL1-treated

Figure 2. The number of M. persicae colonized on control and PeBL1-treated cucumber seedlings (A) $24 \mathrm{~h}$ after the infestation colonization of $M$. persicae (mean $\pm \mathrm{SD}$ ). Data were compared statistically by an ANOVA and LSD in Statistix, version 8.1. Significant differences can be seen in lower style alphabet letters among all treatments $(p=0.05)(\mathbf{B})$ M. persicae colonized and preferred feeding on control cucumber seedlings as compared to the PeBL1-treated seedlings.

\subsection{M. persicae Feeding Behavior by EPG}

An EPG provided a general illustration of the cucumber resistance factors. The feeding behavior of M. persicae in seedlings treated with PeBL1 was significantly altered. EPG data (Table 3) showed that the probing period, the length of $C$ (pathway operation in all tissues), and the sum of M. persicae $\mathrm{Pd}$ (potential decrease in cell punctures) were significantly reduced, whereas the period of non-probe time before the first $\mathrm{E}$ (phloem-feeding activity) and the total duration of $\mathrm{F}$ (penetration problems) in the PeBL1-treated cucumber seedlings increased considerably. No electrical contact between the aphid stylet and the plant was indicated during the non-probing time [29]. In the PeBL1 treatment, the non-probing time before the first $\mathrm{E}$ was dramatically increased, suggesting a repellent or deterrent surface factor in the PeBL1-treated cucumber seedlings. $C$ waves represent style motion in intercellular 
space and may constitute a plant mechanical barrier [30]. The shorter $C$ waves $(<3 \mathrm{~min})$ that were detected, the greater the mechanical difficulty in seedlings treated with PeBL1. Additionally, a lower Pd number (cell puncture) was associated with the plant's aphid resistance, which could have been due to mechanical difficulty (in this study, in the PeBL1-treated cucumber seedlings). The wave E1 (saliva injection during phloem-feeding activities) indicated saliva injection by aphids into sieve elements. In contrast, the E2 wave (sap-sucking during phloem-feeding activities) showed phloem sap injection with concurrent salivation, which could have reflected a mesophyll or vascular resistance factor [31]. In the sieve element [24,31] the extended E1 indicated more plugging or defense compounds. There was, however, no substantial difference between the control and PeBL1 treatments in the E2 period, indicating no or low variability in phloem compounds to confer resistance to M. persicae. However, the period of the F wave in the PeBL1-treated cucumber seedlings was higher, indicating that PeBL1 induced an enhanced mechanical defense. The EPG results suggested that the resistance induced by PeBL1 was mainly due to the modification of the physical defense.

Table 3. Electrical penetration graph (EPG) data of M. persicae on PeBL1-treated and control cucumber seedlings.

\begin{tabular}{ccc}
\hline EPG Parameters & Control $(\mathbf{N}=\mathbf{2 0})$ & PeBL1 $(\mathbf{N}=\mathbf{2 0})$ \\
\hline Total probing time $(\mathrm{h})$ & $3.43 \pm 0.03$ & $2.50 \pm 0.04^{*}$ \\
Number of C & $14.43 \pm 0.06$ & $23.37 \pm 0.45$ \\
Number of short probes (C $<3 \mathrm{~min})$ & $6.34 \pm 0.41$ & $21.19 \pm 0.45$ \\
Duration of non-probe period before the 1st E (h) & $2.45 \pm 0.05$ & $2.49 \pm 0.05^{*}$ \\
Number of pd & $73.09 \pm 0.43$ & $36.53 \pm 0.20$ \\
Mean duration of Pd (s) & $5.71 \pm 0.07$ & $5.60 \pm 0.08$ \\
Number of E1 & $3.44 \pm 0.06$ & $2.75 \pm 0.16$ \\
Mean duration of E1 (min) & $7.12 \pm 0.29$ & $10.83 \pm 0.23$ \\
Number of E2 & $0.88 \pm 0.10$ & $0.69 \pm 0.13$ \\
Mean duration of E2 (h) & $28.77 \pm 0.23$ & $41.91 \pm 0.20$ \\
Number of G & $0.90 \pm 0.17$ & $0.84 \pm 0.10$ \\
Mean Duration of G (min) & $18.19 \pm 0.28$ & $14.32 \pm 0.27$ \\
Number of F & $3.52 \pm 0.25$ & $1.77 \pm 0.19$ \\
mean duration of F (min) & $22.48 \pm 0.38$ & $50.89 \pm 0.23$ \\
\hline
\end{tabular}

Note: Data are shown as mean \pm SD. C stands for pathway activities, Pd stands for potential drop, E stands for phloem-feeding activities, F stands for penetration problem, G stands for xylem feeding activities, E1 stands for saliva injection, and E2 stands for sap-sucking. Data were compared statistically by an independent $t$-test with two tails and Levene's test in Statistix, version 8.1. Asterisks indicate significant differences between PeBL1 treatment and control with the same parameters of $*(p=0.05)$.

\subsection{Impact of PeBL1 Elicitor on Aphid's Nymphal Development Time}

Factorial analysis showed an impact on the overall developmental time of M. persicae on various PeBL1 concentrations in three different temperature regimes and their interaction. A differential trend was identified on the developmental time of nymphs for the elicitor effect at a different temperature, as shown in Tables A6-A10 of Appendix D. With increasing concentrations of PeBL1, (Figure 3A) the development time of each nymphal instar was extended. For the fourth nymphal instar at a high concentration $\left(70.58 \mu \mathrm{g} \mathrm{mL}^{-1}\right)$, the maximum development time was $3.7 \mathrm{~d}$ at the low temperature of $20{ }^{\circ} \mathrm{C}$. At the low concertation $\left(17.64 \mu \mathrm{g} \mathrm{mL}^{-1}\right)$ for the first instar at the high temperature of $27^{\circ} \mathrm{C}$, the minimum nymph growth time was recorded. The time of nymph development (Figure 3B) differed in the buffer control and water-treated control. In general, the nymphal development time of all instars at the low temperature was higher than at medium or high temperatures. At each concentration and temperature of the elicitor, the maximum elongation of time was observed at fourth instar. However, for the first, second, third, and fourth instar aphid concentration of the elicitor, PeBL1 showed significance. Likewise, the effect of temperature regimes also had a significant impact on the developmental time of nymph of the first, second, third, and fourth instar aphids. Afterwards, 
nymphal aphid development time showed little difference across their shared interface. After all, the nymphal development time did not show any fluctuation with their mutual interaction.
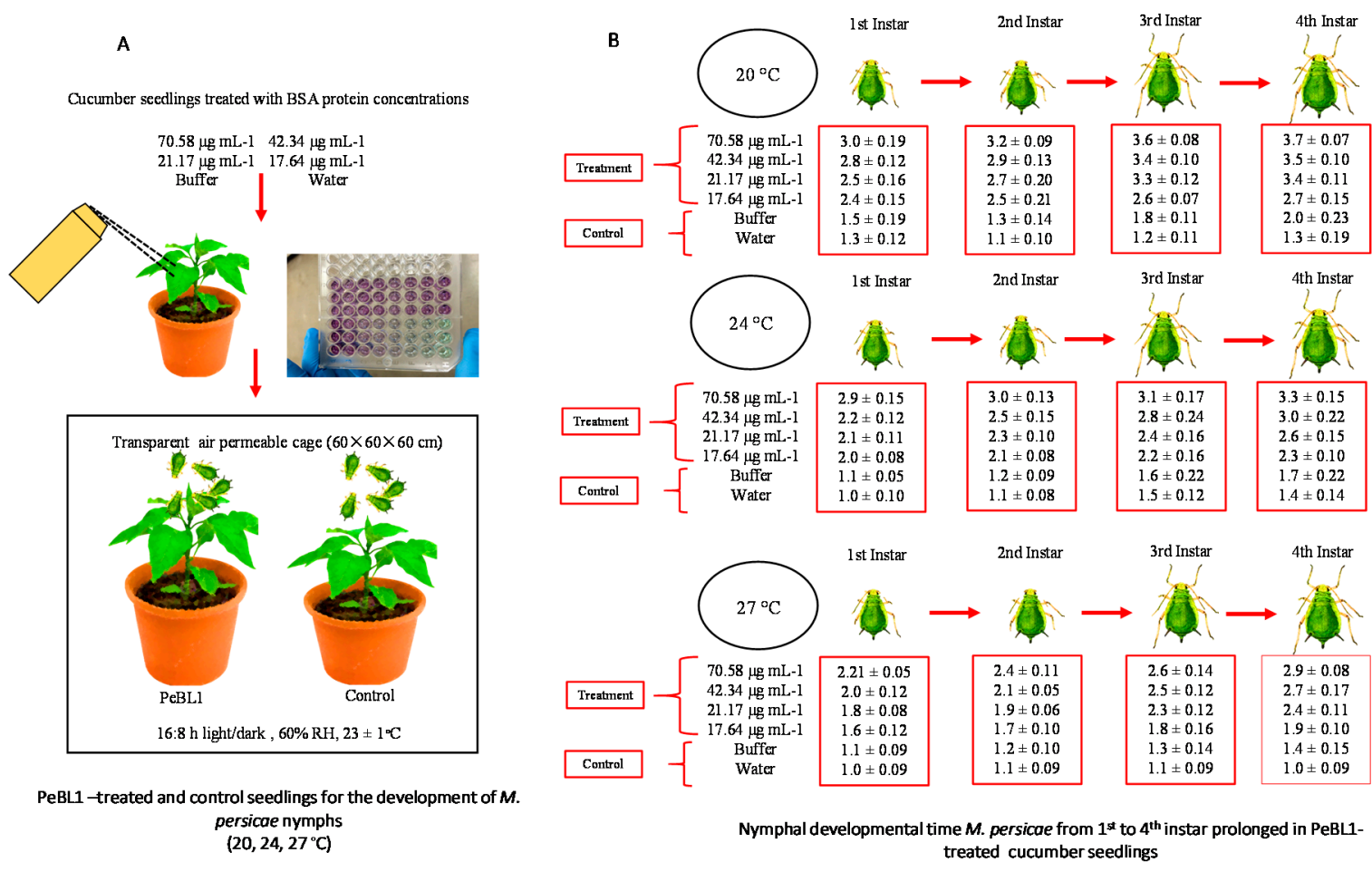

Figure 3. Prolonged nymphal development time of aphid instars (1st, 2nd, 3rd, and 4th). (A) Cucumber seedlings treated with control, buffer, and four PeBL1 protein concentrations prepared by BSA. (B) Nymphal developmental time of M. persicae from the prolonged 1st to 4th instar's in PeBL1-treated cucumber seedlings. Data are shown as the mean $( \pm \mathrm{SE})$ of different nymphal instars of (M. persicae) on cucumber plants by the PeBL1 elicitor protein at different concentrations and different temperature regimes $(n=10)$. Data were compared statistically by a factorial ANOVA and LSD at $\alpha=0.05$ in Statistix, version 8.1. Different alphabets above bar tops specify significant differences among treatments.

\subsection{Effect of PeBL1 Elicitor on the Aphid's Fecundity}

The figures show that the concentrations of PeBL1 $\left(\mathrm{F}_{5.162}=83.82 ; p<0.0001\right)$ and temperature regimes $\left(\mathrm{F}_{2.162}=8.97 ; p<0.0002\right)$ were significantly affected by aphid fecundity, as shown in Appendix $\mathrm{E}$ of Table A11. (Figure 4A,B) shows that M. persicae produced less offspring than those that feed on (water) positive and (buffer) negatively treated cucumber plants in contrast to the PeBL1-treated seedlings (Figure 5). However, a minimum fecundity at a maximum temperature was observed at $27^{\circ} \mathrm{C}$, and a maximum fecundity at a minimum temperature of $20^{\circ} \mathrm{C}$ was recorded.

\subsection{Effect of PeBL1 on the Growth and Structure of Cucumber}

The plant height and surface structure of the cucumber leaves were greatly modified by PeBL1 (Figure 6). A similar trend was also found in the SPAD, the total number of leaves, and plant fresh and dry weight (Tables A12-A16 of Appendix F). In PeBL1-treated seedlings, plant height was greater than that of the control. The surface of cucumber leaves was significantly modified by PeBL1 elicitor protein, seedlings treated with PeBL1 exhibited more trichomes as compared to control in PeBL1 treated $60.84 \pm 0.52 \mathrm{~mm}^{-2}$, while in control treatment it was $34.30 \pm 0.10 \mathrm{~mm}^{-2}$. A more sophisticated wax structure was formed that gave rise to a significantly better surface environment, one that trait is considered to be unfavorable to aphid settlement [32]. 
A Seedlings treated with Control, Buffer and PeBL1 protein concentrations prepared by BSA
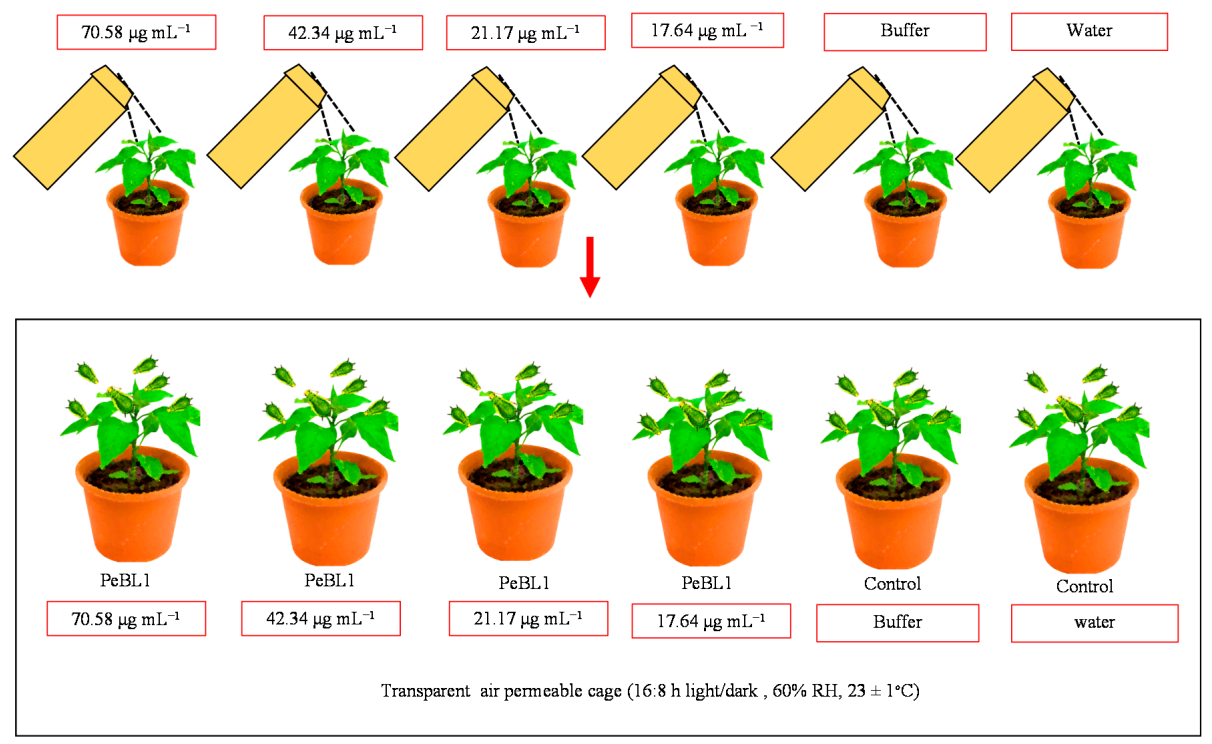

B

PeBL1 and control seedlings for aphid development $\left(20,24,27^{\circ} \mathrm{C}\right)$

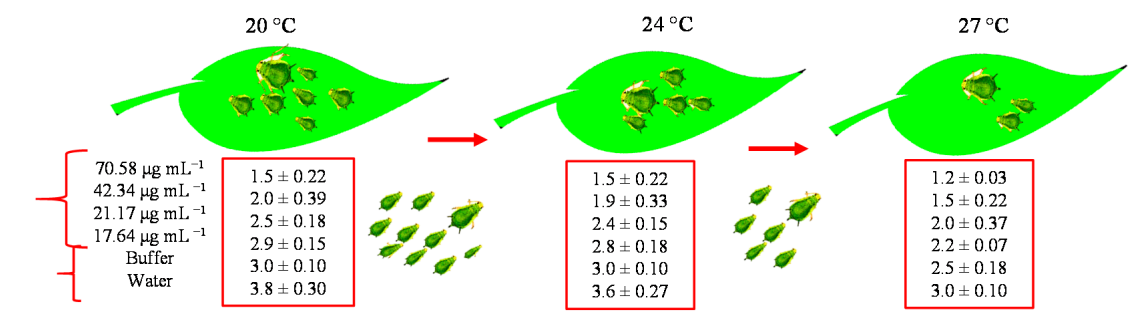

Less number of offspring's in PeBL1 treated seedlings $\left(20,24,27^{\circ} \mathrm{C}\right)$

Figure 4. M. persicae fecundity reduced in PeBL1-treated cucumber seedlings. (A) Seedlings treated with control, buffer, and PeBL1 protein concentrations prepared by BSA. (B) PeBL1 and control seedlings for aphid development $\left(20,24\right.$, and $\left.27^{\circ} \mathrm{C}\right)$. Average fecundity of $M$. persicae on cucumber plant in relation to various PeBL1 concentrations at different temperature regimes $(n=10)$. Data are shown as mean $( \pm$ SE). Data were compared statistically by a factorial ANOVA and LSD at $\alpha=0.05$ in Statistix, version 8.1. Letters on each bar's top show significant differences among treatments.
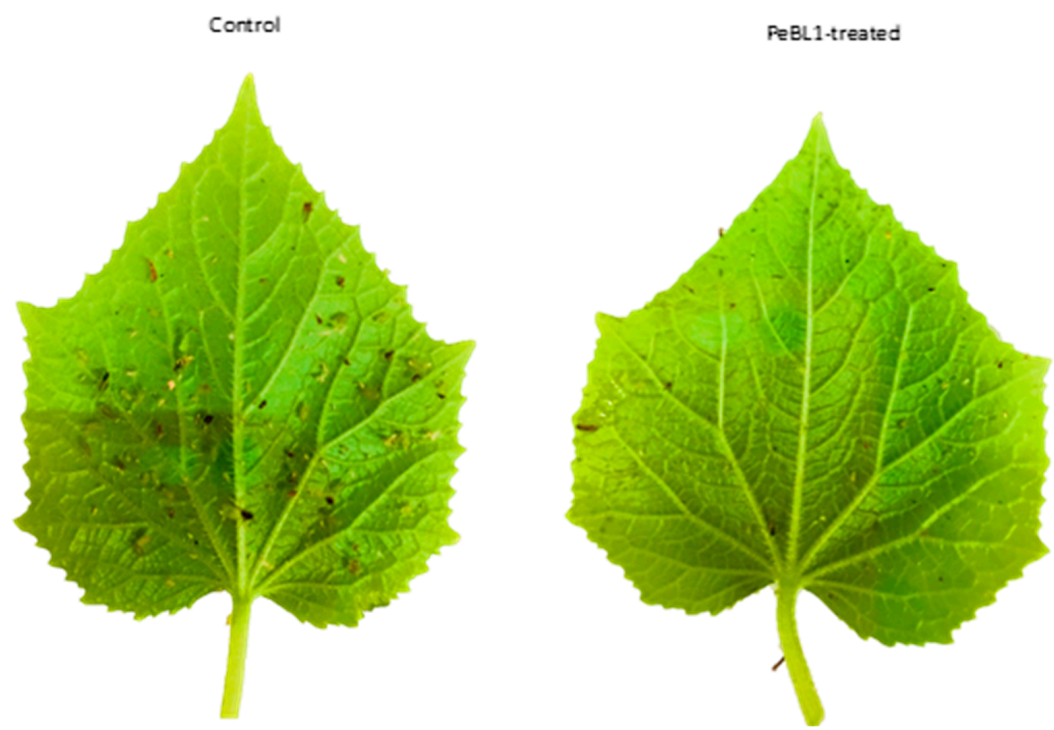

Figure 5. Myzus persicae that fed on PeBL1 showed a reduction in the number of offspring as compared to the control plants. 


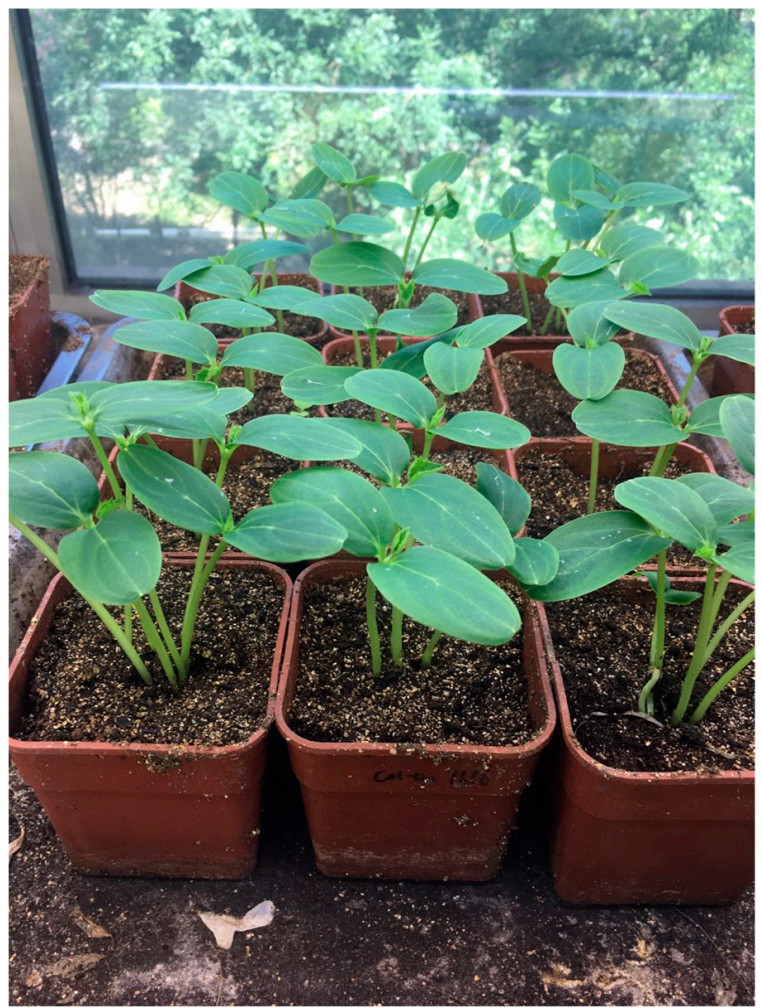

Control

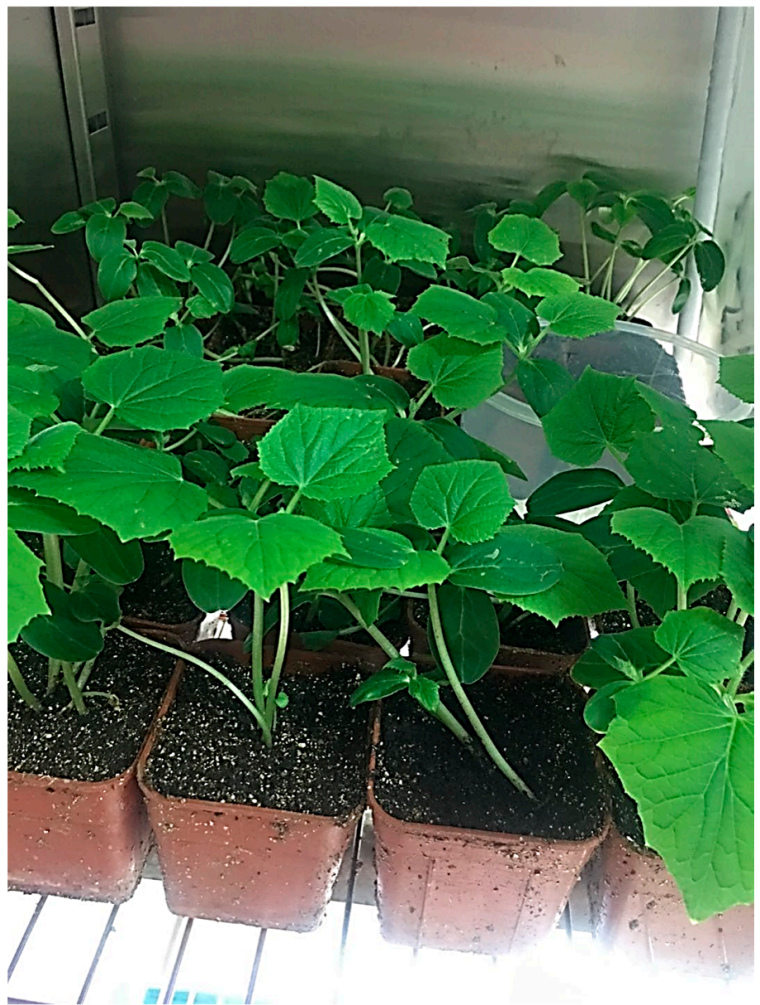

Control and PeBL1- treated cucumber seedlings at three weeks old stage with $16: 8 \mathrm{~h} \mathrm{light} / \mathrm{dark}, 60 \% \mathrm{RH}, 23 \pm 1^{\circ} \mathrm{C}$ Surface structures and plant height significantly enhanced by PeBL1 treatment

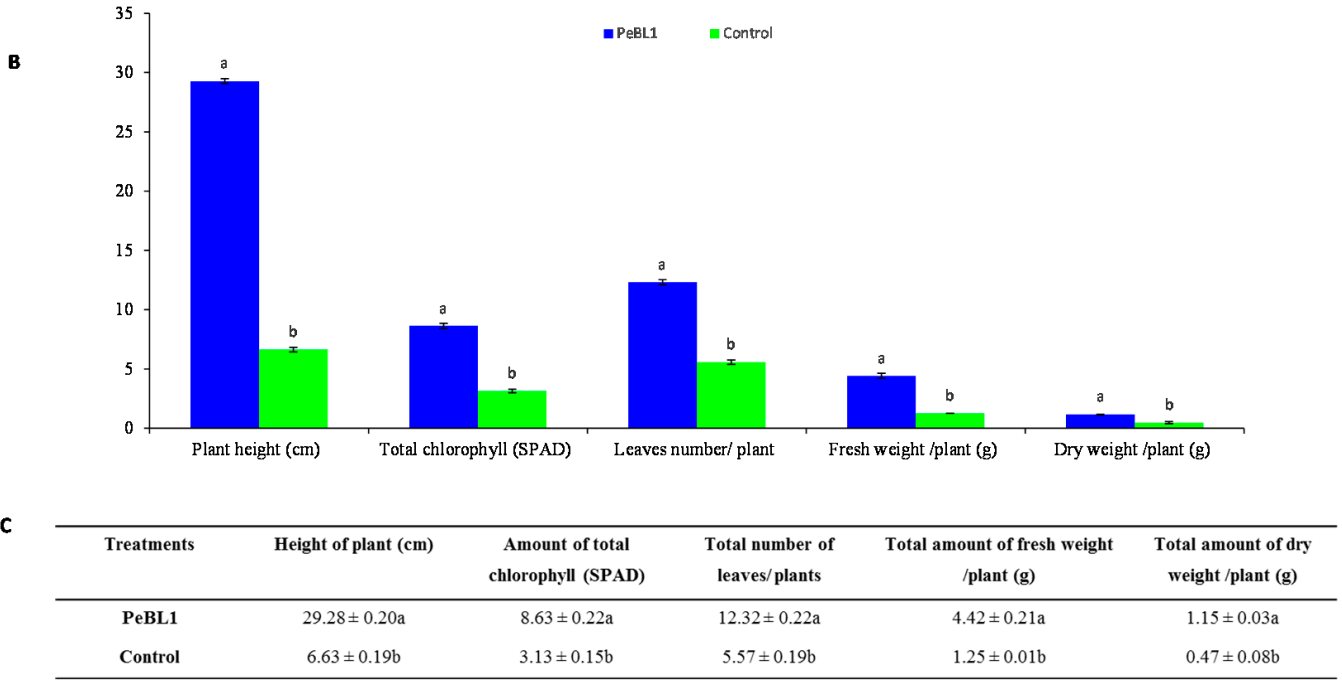

Figure 6. Influence of PeBL1 on the growth of PeBL1-treated and control cucumber seedlings. (A) Plant height increased in PeBL1-treated cucumber seedlings as compared to control (B) Physical characteristics of PeBL1-treated seedlings enhanced as compared to control (C) Data were shown in mean $( \pm \mathrm{SD})$ of cucumber plants in PeBL1-treated and control seedlings $(n=10)$. Data were compared statistically by one-way analysis of variance (ANOVA) and Least significant difference (LSD) in Statistix 8.1 version. Different lower style alphabets letters indicate significant differences among treatments $(p=0.05)$.

\subsection{SA, JA and ET Accumulations in PeBL1-Treated Cucumber Seedlings}

To analyze the relation of JA, SA, and ET with the cuticular wax deposition and increase in the trichome density of PeBL1, the aphid infestation or both were analyzed. PeBL1 showed a very high 
accumulation of JA, SA, and ET in seedlings (Figure 7). All three pathways of signaling were found to participate in aphid-induced cucumber resistance [33]. In addition, JA, SA, and ET accumulated in PeBL1-treated plants, suggesting that the protein elicitor at least partially induced the defense response in cucumber plants. Numbers, infestation rates, and aphid species are known to affect JA, SA, and ET inductions $[34,35]$.

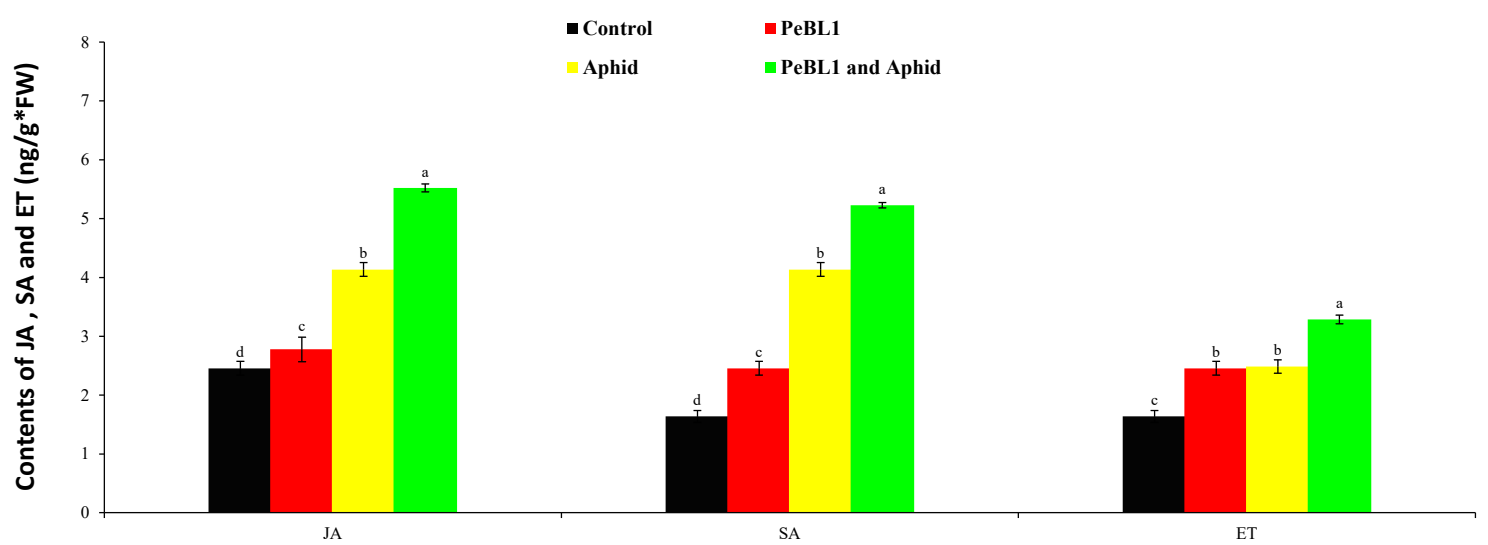

Figure 7. Jasmonic acid (JA), salicylic acid (SA), and ethylene (ET) contents in cucumber seedlings (mean \pm SD). Treatment with PeBL1 was collected one day after spraying. In both treatments, the aphids were inoculated one day after seedlings were sprayed, and the samples were collected one day after inoculation. Data were compared statistically by the LSD, ANOVA, and Leven's test using Statistix, version 8.1. Different lower-case letters show significant differences among various treatments performed in JA, SA, or ET $(p=0.05)$.

\subsection{Relative Fold Expressions of Defense-Related Genes}

PeBL1 enhanced the defense mechanism in cucumber seedlings. ChIT1, $\beta-1,3-$ Glucanase, PAL1, LOX1, PR1, cupi4, PR2, and Pod were selected as test genes for defense pathways. All the genes were up-regulated by treatment with PeBL1 and aphid infestation (Figure 8); the transcripts of all genes were found to be statistically greater with the PeBL1 treatment than with the other two treatments. The idea was that PeBL1 treatment enhanced induced resistance to aphid infestation. The improved transcript of test genes of JA and SA also demonstrated their roles for the JA and SA pathways in aphid resistance in wheat, which was proven by Moron and Thompson. The highest expressed gene was ChIT1, followed by $\beta-1,3-$ Glucanase, PR1, LOX1, PAL1, cupi4, PR2, and Pod. The $\log _{2}$ of all JA, $\mathrm{SA}$, and ET test genes was computed with fold change expression values (Table 4) showed that aphid resistance was due to the transcription of the test genes.

Table 4. $\log _{2}$ of fold change expressions all test genes involved in the JA, SA, and ET pathways after the PeBL1 elicitor application, PeBL1 and aphid, and aphid infestation alone.

\begin{tabular}{cccc}
\hline $\log _{2}$ Fc $_{\text {(Treated/Untreated) }}$ & PeBL1 & Aphid & PeBL1 and Aphid \\
\hline ChIT1 & 1.15 & 0.96 & 1.20 \\
B-1,3Glucanase & 0.89 & 0.99 & 1.05 \\
PAL1 & 0.85 & 1.01 & 1.10 \\
LOX1 & 0.83 & 0.81 & 1.04 \\
PR1 & 0.55 & 0.93 & 1.01 \\
Cupi4 & 0.47 & 0.87 & 0.97 \\
PR2 & 0.43 & 0.62 & 1.09 \\
Pod & 0.35 & 0.89 & 1.13 \\
\hline
\end{tabular}



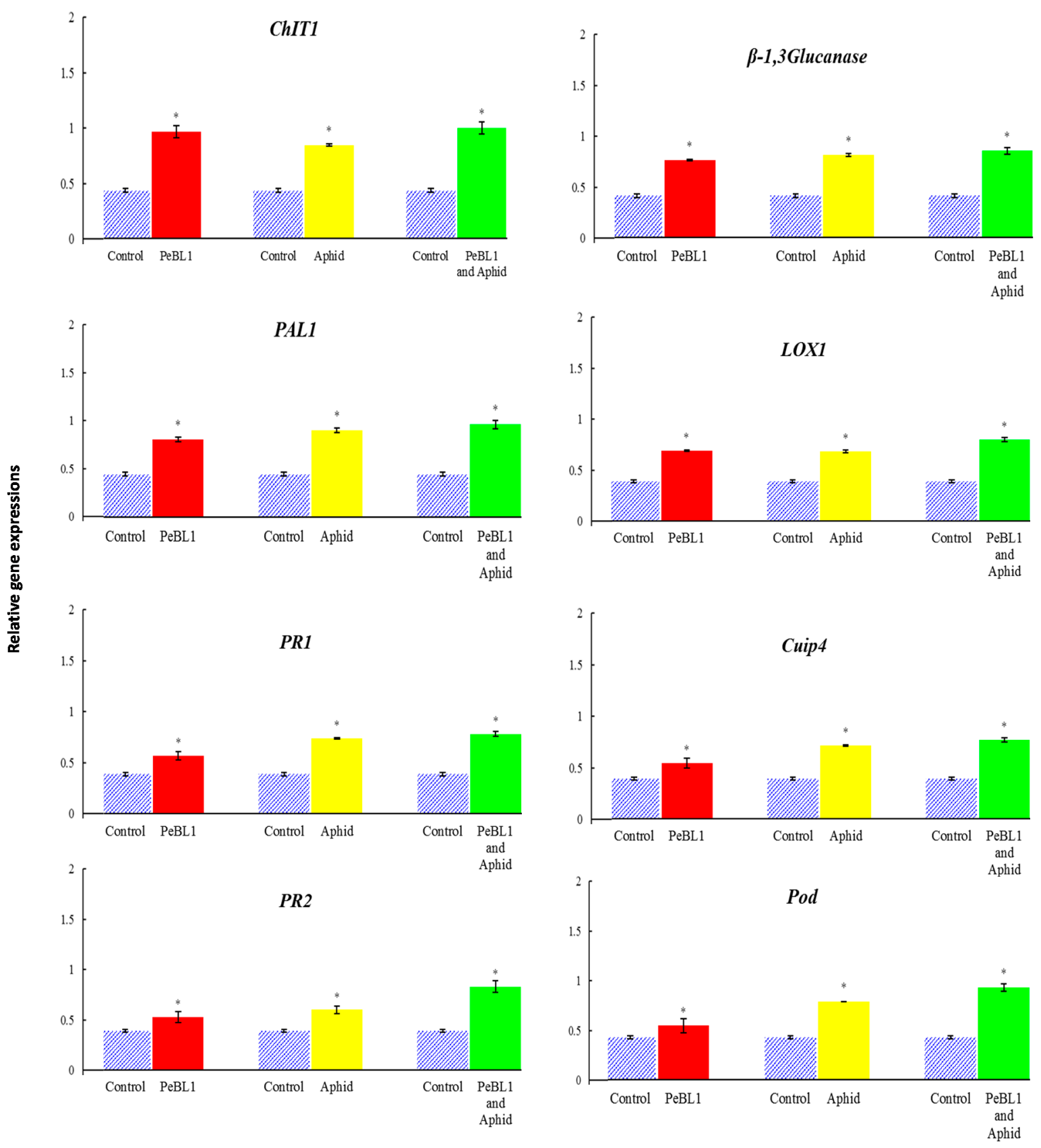

Figure 8. Relative expression of plant defense from the JA, SA, and ET pathway genes found after treatment with the PeBL1 elicitor, PeBL1 and aphid, and aphid infestation alone. For each gene, an asterisk on the bar shows a significant difference from the buffer control, as found by Student's $t$-test $(p<0.05)$.

\section{Discussion}

The use of elicitors is a new biological tool for the management of insect pests, as they play a dynamic role in the defense and signaling mechanisms of plants under the attack of sap-feeding insects $[17,19,20]$, Numerous B. laterosporus strain have demonstrated various broad-spectrum anti-microbial activities, acting as anti-microbial peptides in microbes such as bacteria and fungi. They can enter into the cell and transfer to the cytoplasm and nucleus to interrupt protein synthesis by mixing up DNA and RNA [36,37]. A significant source of elicitors such as PAMPs or MAMPs [38] is pathogenic bacteria and fungi, whether necrotrophic or biotrophic. The potential activities of PeBL1 derived from B. laterosporus strain A60 were demonstrated in this study for M. persicae 
management. Certain studies have previously shown chemical elicitors significantly reduced the activity of herbivorous pests in cucumber crops by applying chemical elicitors, such as methyl-jasmonate, benzothiadiazole, and other plant defenses, including proteinase inhibitors [39]. Results from this study confirmed previous results that the use of methyl salicylate elicitor reduced the soybean aphid Aphis glycines by up to $40 \%$ [38,39]. Here, bioassays showed that population development on PeBL1-treated cucumber plants was significantly slower compared to the buffer and control. Previous studies have shown a negative influence of exogenous applications of elicitors, including MJ, JA, and BTH, on the population growth and fitness of different aphid species, an effect confirmed by the present findings [39]. Similarly, a biocontrol potential was discovered against various Diptera, Coleoptera, and Lepidoptera, as well as against nematodes and mollusks $[23,40]$. The current study showed the ability of PeBL1 to suppress herbivores by influencing population and growth parameters. Trichomes are the first lines of physical resistance to pathogenic microorganisms and herbivores. These hairy adjuncts of plant epidermal cells affect the herbivores' morphology and the density role of trichomes in Solanum spp., i.e., seven trichomes with two major defense-related effects, have been tested [40]. First, a plant surface represents a physical barrier because its thick matte hair provides energy, limits feeding capacity, and reduces access to the surface by insects. Excessively hairy plants, such as Solanum hirsutum, are avoided by M. persicae. Trichomes are also associated with the basic defensive mechanism of the tomato plant, as the surface area covered by the epidermal cell appendages of unicellular or multicellular hairs provide resistance to a variety of pests due to the "pubescence" of a plant. Leaf beetle (Coleoptera: Chrysomelidae) settlement with thick trichomes was reduced in soybeans compared with the trichome-removed plants, which attracted more beetles [41-43]. PeBL1 reduced disease severity, triggering a photosynthesis process that mirrored the characteristics of growth of plants [44], and it enhanced induced-resistance in the PeBL1-treated cucumber seedlings as well.

Compared to the controls, the PeBL1-treated seedlings and leaves had more trichomes. The PeBL1-treated cucumber seedlings and leaflets were reported to have inhibited the reproduction and settlement of aphids with an increased number of trichomes. The feeding activity of Leptinotarsa decemlineata was negatively affected by a high density of trichomes. Another key part of physical barrier lignin is the cell wall, which underpins plant resistance and is an indicator for the improvement of the cell wall [45]. Aphid tolerance in chrysanthemum was amended by an enhanced lignin content [46]. The physical defenses of plants include, in response to biotic and abiotic stress, trichomes and wax production. Their establishment can be induced by direct damage, e.g., as induced by leaf-cuts, methoxyfenozide, and manganese [47,48]. The use of exogenous phytohormones, MJ, or JA can also affect cuticular wax deposition and trichome density, as shown in Arabidopsis and tomatoes, respectively [49]. The SA application was due to wax deposition in Brassica napus [50]. Accumulations of SA and JA in PeBL1-treated cucumber plants can, therefore, be hypothesized as being related to increased trichome density and the deposition of cuticular wax. In addition, the treatment of the PeBL1 elicitor had adverse effects on aphid fecundity. PeBL1-treated plants produced significantly fewer aphids than the buffered and controlled seedlings. The results were consistent with previous studies showing that exogenous SA and MJ have caused lower mean lifetime fecundity in aphids [38]. Therefore, optimum temperatures (e.g., $24^{\circ} \mathrm{C}$ ) demonstrated a maximum aphid fecundity, with the minimum fecundity at higher temperatures $\left(27^{\circ} \mathrm{C}\right)$ due to a decreased metabolic rate [51]. Similarly, a variance analysis showed that in PeBL1-treated plants, the development time of nymphs was extended compared to the control; even at a lower temperature $\left(20^{\circ} \mathrm{C}\right)$, the maximum nymphal development time was observed, indicating that a one-degree temperature increase affected the life cycle of the insect [52]. Additional studies need to be conducted to understand the underlying mechanism of PeBL1 in cucumbers, in particular its effect on fecundity and nymphal development time.

Additionally, JA, SA, and ET increased marker gene transcriptions, signaling that they play an essential role in cucumber aphid resistance. After aphid infestation in Arabidopsis, the transcript genes CHIT1, $\beta$-1,3-glucanase, PR1, LOX1, PAL1, cupi4, PR2, and Pod were significantly increased. Actin is a structural component in the plant cell wall that is depolymerized via the regulation of 
cell and cross-linking [53,54]. Actin depolymerization is negatively related to aphid fecundity and population [55]. JA, SA, and ET molecules impart resistance to insect herbivorous diseases and pathogens, which enhances plant defense responses [12,56-58]. All JA, SA, and ET test genes showed significant and robust regulation [12]. PAL1 coding for ammonia-lyase phenylalanine is involved in cell wall construction, as demonstrated in Arabidopsis [59]. JA and LOX1 up-regulation occur in cucumber plant Pseudomonas injection [59,60]. PR1 and PR2 are systemically acquired (SAR) pathogenesis-related proteins $[13,61,62]$. Cupi4 genes with antibacterial characteristics also lead to the induction of hypersensitive reactions in the infected tissues of plants $[63,64]$. The presence of CHIT1 (PR-3 family) genes indicates fungal cell wall damage in plants due to antifungal activity $[13,65]$. $\beta-1,3-$ Glucanase (beta-glucanase) codes show a plant-friendly defense mechanism against several microorganisms, as well as an increase in $\beta-1,3$-glucanase in P. melonis fungal cell walls, which leads to the inhibition of disease growth in infected plants [66,67]. Pod codes peroxidase, which indicates that the acclimation of the Pod will mediate aphid resistance in cucumbers [68]. Experimental findings from this research confirm that the activation of Pod by M. persicae induces genes associated with the defense pathway [69].

\section{Conclusions}

Herein, we present data on aphid resistance in cucumbers with the prolonged developmental time of the first to fourth nymphal instars, related to a lower fecundity of $M$. persicae. Increased PeBL1 concentrations were found to affect aphid colonization. The resistance factors were verified by the increased number of trichomes and wax amounts, which were mainly involved in mechanical defenses. Likewise, an EPG study confirmed that the resistance induced by PeBL1 was mainly due to the modification of the physical defense and increased number of trichomes, and wax composition affected aphid feeding behavior in PeBL1-treated. Moreover, our study focused on the effect of PeBL1 on the growth and structure of cucumber, and we found that increased plant height and modified surface structures of the cucumber leaves were greatly influenced by PeBL1. We also confirmed the role of PeBL1 in physical defense against $M$. persicae. The physical defense response induced by PeBL1, JA, SA, and ET contributed to a comprehensive plant physical response.

However, some issues need to be resolved in the future, e.g., "how JA, SA and ET work resistance induction," and "whether or not other plant hormones are involved." Nevertheless, the current study showed that PeBL1 isolated from B. laterosporus A60 strain could be applied to cucumber seed and seedlings to protect plants against $M$. persicae.

Author Contributions: K.J. designed and performed the experimental work, including paper writing and data analysis. H.J. provided help in managing data analysis. D.Q. supervised the whole experiment and provided help in revising the article. The experiment was carried out in the State Key Laboratory for Biology of Plant Diseases and Insect Pests, Institute of Plant Protection, Chinese Academy of Agricultural Sciences, No. 12 Zhong-Guan-Cun South Street, Beijing 100081, China. All authors have read and agreed to the published version of the manuscript.

Funding: The study was supported by National Key Research and Development Program of China (2017YFDO200900).

Acknowledgments: The authors sincerely thank Toby Bruce, and David Buss from Keele University, the UK for extensive language editing of this manuscript. Kashan Khan helped with data presented in the article. The experiments were carried out in the State Key Laboratory for Biology of Plant Diseases and Insect Pests, Institute of Plant Protection, Chinese Academy of Agricultural Sciences, No. 12 Zhong-Guan-Cun South Street, Beijing 100081, China.

Conflicts of Interest: The author declares no conflict of interest. 


\section{Appendix A}

Table A1. Primers of all test genes JA, SA, and ET involved in plant defense.

\begin{tabular}{|c|c|c|}
\hline Test Gene & Forward Sequence $\left(5^{\prime} \ldots . . .3^{\prime}\right)$ & Reverse Sequence $\left(5^{\prime} \ldots . . .3^{\prime}\right)$ \\
\hline CHIT1 & TGGTCACTGCAACCCTGACA & AGGGTGAAAGCAAGAAGAGC \\
\hline$\beta-1,3$ Glucanase & TCAATTATCAAAACTTGTTCGATGC & AACCСТCTGGTAGGACAACAAC \\
\hline PAL1 & ATGGAGGCAACTTCCAAGGA & CCATGGCAATCTCAGCACCT \\
\hline PR1 & TGCTCAACAA ATGCGAACC & TCATCCACCCACAACTGAAC \\
\hline LOX1 & CTCTTGGGTGGTGGTGTTTC & TGGTGGGATTGAAGTTAGCC \\
\hline Cupi4 & TCACTGTGGTGTGTGCTCTC & ACTCAA GCCATTGCCTTCCA \\
\hline PR2 & TCAAGGAAGGTTCAGGGATG & TCGGTGATCCATTCTTCACA \\
\hline pod & TCAGGATGGGAAATCTCGAC & CGTGGCCAACTCATACACAC \\
\hline $18 S$ & GTGACGGGTGACGGAGAATT & GACACTAATGCGCCCGGTAT \\
\hline
\end{tabular}

\section{Appendix B}

Table A2. Differences of M. persicae number after 5 days in PeBL1-treated, buffer, and control cucumber seedlings.

\begin{tabular}{cccccc}
\hline SOV & DF & SS & MS & F-Value & $p$-Value \\
\hline Treatments & 2 & 1323.43 & 661.713 & 110 & 0.0001 \\
Error & 27 & 162.24 & 6.009 & & \\
Total & 29 & 1485.67 & & & \\
\hline Grand Mean/CV & $2.45 / 28.49$ & & \\
\hline
\end{tabular}

Table A3. Differences of M. persicae number after 10 days in PeBL1-treated, buffer, and control cucumber seedlings.

\begin{tabular}{cccccc}
\hline SOV & DF & SS & MS & F-Value & $p$-Value \\
\hline Treatments & 2 & 5938.56 & 2969.28 & 143 & 0.0001 \\
Error & 27 & 560.46 & 20.76 & & \\
Total & 29 & 6499.02 & & & \\
\hline Grand Mean/CV & $105.45 / 4.32$ & & \\
\hline
\end{tabular}

Table A4. Differences of M. persicae number after 15 days in PeBL1-treated, buffer, and control cucumber seedlings.

\begin{tabular}{cccccc}
\hline SOV & DF & SS & MS & F-Value & $p$-Value \\
\hline Treatments & 2 & 29442.1 & 14721.1 & 722 & 0.0002 \\
Error & 27 & 550.3 & 20.4 & & \\
Total & 29 & 29992.4 & & & \\
\hline Grand Mean/CV & $213.62 / 2.11$ & & \\
\hline
\end{tabular}

\section{Appendix C}

Table A5. Number of M. persicae colonized on control cucumber seedlings, PeBL1-treated cucumber seedlings, and elsewhere.

\begin{tabular}{cccccc}
\hline SOV & DF & SS & MS & F-Value & $p$-Value \\
\hline Treatments & 2 & 498.05 & 249.02 & 561 & 0.0001 \\
Error & 27 & 11.97 & 0.44 & & \\
Total & 29 & 510.02 & & & \\
\hline Grand Mean/CV & $8.83 / 7.54$ & & \\
\hline
\end{tabular}




\section{Appendix D}

Table A6. Nymphal development time of 1st instar (M. persicae) in relation to PeBL1 elicitor and temperature.

\begin{tabular}{cccccc}
\hline SOV & DF & SS & MS & F-Value & $p$-Value \\
\hline Conc. & 5 & 53.22 & 10.64 & 72.46 & 0.0001 \\
Temp. & 2 & 10.93 & 5.46 & 37.23 & 0.0001 \\
Conc. $\times$ Temp. & 10 & 3.32 & 0.33 & 2.26 & 0.0167 \\
Error & 162 & 23.79 & 0.14 & & \\
Total & 179 & 91.28 & & & \\
\hline Grand Mean/CV & \multicolumn{7}{c}{$1.99 / 19.32$} & \\
\hline
\end{tabular}

Table A7. Nymphal development time of 2nd instar (M. persicae) in relation to PeBL1 elicitor and temperature.

\begin{tabular}{cccccc}
\hline SOV & DF & SS & MS & F-Value & $p$-Value \\
\hline Conc. & 5 & 67.25 & 13.45 & 94.87 & 0.0000 \\
Temp. & 2 & 10.53 & 5.26 & 37.16 & 0.0000 \\
Conc. $\times$ Temp. & 10 & 3.75 & 0.37 & 2.65 & 0.0000 \\
Error & 162 & 22.96 & 0.14 & & \\
Total & 179 & 104.50 & & & \\
\hline Grand Mean/CV & $2.05 / 18.33$ & & \\
\hline
\end{tabular}

Table A8. Nymphal development time of 3rd instar (M. persicae) in relation to PeBL1 elicitor and temperature.

\begin{tabular}{cccccc}
\hline SOV & DF & SS & MS & F-Value & $p$-Value \\
\hline Conc. & 5 & 75.06 & 15.01 & 75.63 & 0.0001 \\
Temp. & 2 & 19.93 & 9.96 & 50.21 & 0.0001 \\
Conc. $\times$ Temp. & 10 & 2.33 & 0.23 & 1.18 & 0.3103 \\
Error & 162 & 32.15 & 0.19 & & \\
Total & 179 & 129.49 & & & \\
\hline Grand Mean/CV & $2.05 / 18.33$ & \\
\hline
\end{tabular}

Table A9. Nymphal development time of 4 th instar (M. persicae) in relation to PeBL1 elicitor and temperature.

\begin{tabular}{cccccc}
\hline SOV & DF & SS & MS & F-Value & $p$-Value \\
\hline Conc. & 5 & 83.88 & 16.57 & 74.27 & 0.0001 \\
Temp. & 2 & 18.28 & 9.14 & 40.97 & 0.0001 \\
Conc. $\times$ Temp. & 10 & 1.33 & 0.13 & 0.60 & 0.8131 \\
Error & 162 & 36.15 & 0.22 & & \\
Total & 179 & 138.62 & & & \\
\hline Grand Mean/CV & $2.45 / 28.49$ & & \\
\hline
\end{tabular}


Table A10. Nymphal development time of overall (M. persicae) in relation to PeBL1 elicitor and temperature.

\begin{tabular}{cccccc}
\hline SOV & DF & SS & MS & F-Value & $p$-Value \\
\hline Conc. & 5 & 1096.89 & 219.37 & 199.77 & 0.0001 \\
Temp. & 2 & 231.52 & 115.76 & 105.41 & 0.0001 \\
Conc. $\times$ Temp. & 10 & 30.25 & 3.052 & 2.78 & 0.0034 \\
Error & 162 & 177.90 & 2.73 & & \\
Total & 179 & 1536.84 & & & \\
\hline Grand Mean/CV & $8.89 / 11.79$ \\
\hline
\end{tabular}

\section{Appendix E}

Table A11. Fecundity of M. persicae in relation to PeBL1 elicitor and temperature (ANOVA).

\begin{tabular}{cccccc}
\hline SOV & DF & SS & MS & F-Value & $p$-Value \\
\hline Conc. & 5 & 83.82 & 16.7644 & 34.14 & 0.0000 \\
Temp. & 2 & 8.973 & 4.4864 & 9.14 & 0.0002 \\
Conc. $\times$ Temp. & 10 & 1.952 & 0.1952 & 0.40 & 0.9463 \\
Error & 162 & 79.548 & 0.4910 & & \\
Total & 179 & 174.294 & & & \\
\hline Grand Mean/CV & $2.45 / 28.49$ & \\
\hline
\end{tabular}

\section{Appendix F}

Table A12. Influence on the plant height of PeBL1-treated and control cucumber seedlings.

\begin{tabular}{cccccc}
\hline SOV & DF & SS & MS & F-Value & $p$-Value \\
\hline Treatments & 1 & 2567.60 & 2567.60 & 67921 & 0.0001 \\
Error & 18 & 0.68 & 0.04 & & \\
Total & 19 & 2568.29 & & & \\
\hline Grand Mean/CV & \multicolumn{7}{c}{$17.95 / 1.08$} & & \\
\hline
\end{tabular}

Table A13. Influence on the total amount of chlorophyll (SPAD) of PeBL1-treated and control cucumber seedlings.

\begin{tabular}{cccccc}
\hline SOV & DF & SS & MS & F-Value & $p$-Value \\
\hline Treatments & 1 & 136.86 & 136.869 & 3681 & 0.0002 \\
Error & 18 & 0.669 & 0.037 & & \\
Total & 19 & 137.538 & & & \\
\hline Grand Mean/CV & $6.04 / 3.19$ & & \\
\hline
\end{tabular}

Table A14. Influence on the total number of leaves/plants of PeBL1-treated and control cucumber seedlings.

\begin{tabular}{cccccc}
\hline SOV & DF & SS & MS & F-Value & $p$-Value \\
\hline Treatments & 1 & 227.94 & 227.94 & 5402 & 0.0002 \\
Error & 18 & 0.760 & 0.042 & & \\
Total & 19 & 228.70 & & & \\
\hline Grand Mean/CV & \multicolumn{2}{c}{$8.94 / 2.30$} & & \\
\hline
\end{tabular}


Table A15. Influence on the total amount of fresh weight per plant (g) of PeBL1-treated, and control cucumber seedlings.

\begin{tabular}{cccccc}
\hline SOV & DF & SS & MS & F-Value & $p$-Value \\
\hline Treatments & 1 & 50.27 & 50.27 & 2377 & 0.0001 \\
Error & 18 & 0.38 & 0.02 & & \\
Total & 19 & 50.65 & & & \\
\hline Grand Mean/CV & \multicolumn{2}{c}{$2.83 / 5.13$} & & \\
\hline
\end{tabular}

Table A16. Influence on the total amount of dry weight per plant (g) of PeBL1-treated, and control cucumber seedlings.

\begin{tabular}{cccccc}
\hline SOV & DF & SS & MS & F-Value & $p$-Value \\
\hline Treatments & 1 & 2.32 & 2.32 & 698 & 0.0564 \\
Error & 18 & 0.05 & 0.0033 & & \\
Total & 19 & 2.38 & & & \\
\hline Grand Mean/CV & \multicolumn{7}{c}{$0.81 / 7.13$} & & \\
\hline
\end{tabular}

\section{References}

1. Walling, L.L. The myriad plant responses to herbivores. J. Plant Growth Regul. 2000, 19, 195-216.

2. Zhao, L.Y.; Chen, J.L.; Cheng, D.F.; Sun, J.R.; Liu, Y.; Tian, Z. Biochemical and molecular characterizations of Sitobion avenae-induced wheat defense responses. Crop Prot. 2009, 28, 435-442.

3. Ahuja, I.; Rohloff, J.; Bones, A.M. Defence mechanisms of brassicaceae: Implications for plant-insect interactions and potential for integrated pest management. Sustain. Agric. 2009, 2, 623-670.

4. Girousse, C.; Moulia, B.; Silk, W.; Bonnemain, J.L. Aphid infestation causes different changes in carbon and nitrogen allocation in alfalfa stems as well as different inhibitions of longitudinal and radial expansion. Plant Physiol. 2005, 137, 1474-1484.

5. Jakobs, R.; Schweiger, R.; Müller, C. Aphid infestation leads to plant part-specific changes in phloem sap chemistry, which may indicate niche construction. New Phytol. 2019, 221, 503-514.

6. De Vos, M.; Jander, G. Myzus persicae (green peach aphid) salivary components induce defence responses in Arabidopsis thaliana. Plant Cell Environ. 2009, 32, 1548-1560.

7. Saad, K.A.; Mohamad Roff, M.N.; Hallett, R.H.; Idris, A.B. Aphid-induced Defences in Chilli Affect Preferences of the Whitefly, Bemisia tabaci (Hemiptera: Aleyrodidae). Sci. Rep. 2015, 5, 1-9.

8. Nouri-Ganbalani, G.; Borzoui, E.; Shahnavazi, M.; Nouri, A. Induction of resistance against Plutella xylostella (L.) (Lep.: Plutellidae) by jasmonic acid and mealy cabbage aphid feeding in Brassica napus L. Front. Physiol. 2018, 9, 859 .

9. Salzman, R.A.; Brady, J.A.; Finlayson, S.A.; Buchanan, C.D.; Summer, E.J.; Sun, F.; Klein, P.E.; Klein, R.R.; Pratt, L.H.; Cordonnier-Pratt, M.M.; et al. Transcriptional profiling of sorghum induced by methyl jasmonate, salicylic acid, and aminocyclopropane carboxylic acid reveals cooperative regulation and novel gene responses. Plant Physiol. 2005, 138, 352-368.

10. Lazebnik, J.; Frago, E.; Dicke, M.; van Loon, J.J.A. Phytohormone Mediation of Interactions Between Herbivores and Plant Pathogens. J. Chem. Ecol. 2014, 40, 730-741.

11. Ali, J.G.; Agrawal, A.A. Asymmetry of plant-mediated interactions between specialist aphids and caterpillars on two milkweeds. Funct. Ecol. 2014, 28, 1404-1412.

12. Derbalah, A.; Elsharkawy, M.M.; Hamza, A.; El-Shaer, A. Resistance induction in cucumber and direct antifungal activity of zirconium oxide nanoparticles against Rhizoctonia solani. Pestic. Biochem. Physiol. 2019, 157, 230-236.

13. Shoresh, M.; Yedidia, I.; Chet, I. Involvement of jasmonic acid/ethylene signaling pathway in the systemic resistance induced in cucumber by Trichoderma asperellum T203. Phytopathology 2005, 95, 76-84.

14. Zhao, J.; Davis, L.C.; Verpoorte, R. Elicitor signal transduction leading to production of plant secondary metabolites. Biotechnol. Adv. 2005, 23, 283-333. 
15. Ellis, J.G.; Rafiqi, M.; Gan, P.; Chakrabarti, A.; Dodds, P.N. Recent progress in discovery and functional analysis of effector proteins of fungal and oomycete plant pathogens. Curr. Opin. Plant Biol. 2009, 12, $399-405$.

16. Montesano, M.; Brader, G.; Palva, E.T. Pathogen derived elicitors: Searching for receptors in plants. Mol. Plant Pathol. 2003, 4, 73-79.

17. Javed, K.; Qiu, D. Protein Elicitor PeBL1 of Bravibacillus laterosporus Enhances Resistance Against Myzus persicae in Tomato. Pathogens 2020, 9, 57.

18. Hael-Conrad, V.; Perato, S.M.; Arias, M.E.; Martínez-Zamora, M.G.; Di Peto, P.D.L.Á.; Martos, G.G.; Castagnaro, A.P.; Díaz-Ricci, J.C.; Chalfoun, N.R. The elicitor protein AsES induces a systemic acquired resistance response accompanied by systemic microbursts and micro-hypersensitive responses in Fragaria ananassa. Mol. Plant-Microbe Interact. 2018, 31, 46-60.

19. Javed, K.; Javed, H.; Mukhtar, T.; Qiu, D. Pathogenicity of some entomopathogenic fungal strains to green peach aphid, Myzus persicae Sulzer (Homoptera: Aphididae). Egypt. J. Biol. Pest Control 2019, 29, 1-7.

20. Javed, K.; Javed, H.; Mukhtar, T.; Qiu, D. Efficacy of beauveria bassiana and verticillium lecanii for the management of whitefly and aphid. Pak. J. Agric. Sci. 2019, 56, 669-674.

21. Wang, H.; Yang, X.; Guo, L.; Zeng, H.; Qiu, D. PeBL1, a novel protein elicitor from Brevibacillus laterosporus strain A60, activates defense responses and systemic resistance in Nicotiana benthamiana. Appl. Environ. Microbiol. 2015, 81, 2706-2716.

22. Ruiu, L.; Delrio, G.; Ellar, D.J.; Floris, I.; Paglietti, B.; Rubino, S.; Satta, A. Lethal and sublethal effects of Brevibacillus laterosporus on the housefly (Musca domestica). Entomol. Exp. Appl. 2006, 118, 137-144.

23. Ruiu, L.; Satta, A.; Floris, I. Emerging entomopathogenic bacteria for insect pest management. Bull. Insectology 2013, 66, 181-186.

24. Li, L.; Wang, S.; Yang, X.; Francis, F.; Qiu, D. Protein elicitor PeaT1 enchanced resistance against aphid (Sitobion avenae) in wheat. Pest Manag. Sci. 2019, 76, 236-243.

25. Sarria, E.; Cid, M.; Garzo, E.; Fereres, A. Excel Workbook for automatic parameter calculation of EPG data. Comput. Electron. Agric. 2009, 67, 35-42.

26. Li, Y.H.; Wei, F.; Dong, X.Y.; Peng, J.H.; Liu, S.Y.; Chen, H. Simultaneous analysis of multiple endogenous plant hormones in leaf tissue of oilseed rape by solid-phase extraction coupled with high-performance liquid chromatography-electrospray ionisation tandem mass spectrometry. Phytochem. Anal. 2011, 22, 442-449.

27. Jarošová, J.; Kundu, J.K. Validation of reference genes as internal control for studying viral infections in cereals by quantitative real-time RT-PCR. BMC Plant Biol. 2010, 10, 146.

28. Livak, K.J.; Schmittgen, T.D. Analysis of relative gene expression data using real-time quantitative PCR and the $2^{-\Delta \Delta C T}$ method. Methods 2001, 25, 402-408.

29. Alvarez, A.E.; Tjallingii, W.F.; Garzo, E.; Vleeshouwers, V.; Dicke, M.; Vosman, B. Location of resistance factors in the leaves of potato and wild tuber-bearing Solanum species to the aphid Myzus persicae. Entomol. Exp. Appl. 2006, 121, 145-157.

30. Garzo, E.; Soria, C.; Gomez-Guillamon, M.L.; Fereres, A. Feeding behavior of Aphis gossypii on resistant accessions of different melon genotypes (Cucumis melo). Phytoparasitica 2002, 30, 129-140.

31. Montllor, C.B.; Tjallingii, W.F. Stylet penetration by two aphid species on susceptible and resistant lettuce. Entomol. Exp. Appl. 1989, 52, 103-111.

32. Levin, D.A. The Role of Trichomes in Plant Defense. Q. Rev. Biol. 1973, 48, 3-15.

33. Smith, C.M.; Boyko, E.V. The molecular bases of plant resistance and defense responses to aphid feeding: Current status. Entomol. Exp. Appl. 2007, 122, 1-16.

34. Stewart, S.A.; Hodge, S.; Bennett, M.; Mansfield, J.W.; Powell, G. Aphid induction of phytohormones in Medicago truncatula is dependent upon time post-infestation, aphid density and the genotypes of both plant and insect. Arthropod-Plant Interact. 2016, 10, 41-53.

35. Mai, V.C.; Drzewiecka, K.; Jeleń, H.; Narozna, D.; Rucińska-Sobkowiak, R.; Kesy, J.; Floryszak-Wieczorek, J.; Gabryś, B.; Morkunas, I. Differential induction of Pisum sativum defense signaling molecules in response to pea aphid infestation. Plant Sci. 2014, 221-222, 1-12.

36. Bale, J.S.; Masters, G.J.; Hodkinson, I.D.; Awmack, C.; Bezemer, T.M.; Brown, V.K.; Butterfield, J.; Buse, A.; Coulson, J.C.; Farrar, J.; et al. Herbivory in global climate change research: Direct effects of rising temperature on insect herbivores. Glob. Chang. Biol. 2002, 8, 1-16.

37. Brogden, K.A. Antimicrobial peptides: Pore formers or metabolic inhibitors in bacteria? Nat. Rev. Microbiol. 2005, 3, 238-250. 
38. Boughton, A.J.; Hoover, K.; Felton, G.W. Impact of chemical elicitor applications on greenhouse tomato plants and population growth of the green peach aphid, Myzus persicae. Entomol. Exp. Appl. 2006, 120, 175-188.

39. Mallinger, R.E.; Hogg, D.B.; Gratton, C. Methyl Salicylate Attracts Natural Enemies and Reduces Populations of Soybean Aphids (Hemiptera: Aphididae) in Soybean Agroecosystems. J. Econ. Entomol. 2011, 104, 115-124.

40. Schaller, F.; Schaller, A.; Stintzi, A. Biosynthesis and metabolism of jasmonates. J. Plant Growth Regul. 2004, 23, 179-199.

41. Lam, W.-K.F.; Pedigo, L.P. Effect of Trichome Density on Soybean Pod Feeding by Adult Bean Leaf Beetles (Coleoptera: Chrysomelidae). J. Econ. Entomol. 2009, 94, 1459-1463.

42. Bahlmann, L.; Botha, A.M.; Govender, P. Leaf epicuticular wax ultrastructure and trichome presence on Russian wheat aphid (Diuraphis noxia) resistant and susceptible leaves. Afr. Entomol. 2003, 11, 59-64.

43. Glas, J.J.; Schimmel, B.C.J.; Alba, J.M.; Escobar-Bravo, R.; Schuurink, R.C.; Kant, M.R. Plant glandular trichomes as targets for breeding or engineering of resistance to herbivores. Int. J. Mol. Sci. 2012, 13, 17077-17103.

44. Shenashen, M.; Derbalah, A.; Hamza, A.; Mohamed, A.; El Safty, S. Antifungal activity of fabricated mesoporous alumina nanoparticles against root rot disease of tomato caused by Fusarium oxysporium. Pest Manag. Sci. 2017, 73, 1121-1126.

45. Tian, D.; Tooker, J.; Peiffer, M.; Chung, S.H.; Felton, G.W. Role of trichomes in defense against herbivores: Comparison of herbivore response to woolly and hairless trichome mutants in tomato (Solanum lycopersicum). Planta 2012, 236, 1053-1066.

46. Wang, Y.; Sheng, L.; Zhang, H.; Du, X.; An, C.; Xia, X.; Chen, F.; Jiang, J.; Chen, S. CmMYB19 over-expression improves aphid tolerance in chrysanthemum by promoting lignin synthesis. Int. J. Mol. Sci. 2017, 18, 619.

47. Zheng, M.; Chen, J.; Shi, Y.; Li, Y.; Yin, Y.; Yang, D.; Luo, Y.; Pang, D.; Xu, X.; Li, W.; et al. Manipulation of lignin metabolism by plant densities and its relationship with lodging resistance in wheat. Sci. Rep. 2017, 7, 1-12.

48. Tozin, L.R.d.S.; Marques, M.O.M.; Rodrigues, T.M. Herbivory by leaf-cutter ants changes the glandular trichomes density and the volatile components in an aromatic plant model. AoB Plants 2017, 9, 1-8.

49. Boughton, A.J.; Hoover, K.; Felton, G.W. Methyl jasmonate application induces increased densities of glandular trichomes on tomato, Lycopersicon esculentum. J. Chem. Ecol. 2005, 31, 2211-2216.

50. Ni, Y.; Wang, J.; Song, C.; Xia, R.-E.; Sun, Z.-Y.; Guo, Y.-J.; Li, J.-N. Effects of SA Induction on Leaf Cuticular Wax and Resistance to Sclerotinia sclerotiorurn in Brassica napus. Acta Agron. Sin. 2013, 39, 110-117.

51. Farmer, E.E.; Johnson, R.R.; Ryan, C.A. Regulation of expression of proteinase inhibitor genes by methyl jasmonate and jasmonic acid. Plant Physiol. 1992, 98, 995-1002.

52. Mahmoud, F.; Mahfouz, H. Effects of salicylic acid elicitor against aphids on wheat and detection of infestation using infrared thermal imaging technique in Ismailia, Egypt. Pesticidi i Fitomedicina 2015, 30, 91-97.

53. Kots, K.; Meijer, H.J.G.; Bouwmeester, K.; Govers, F.; Ketelaar, T. Filamentous actin accumulates during plant cell penetration and cell wall plug formation in Phytophthora infestans. Cell. Mol. Life Sci. 2017, 74, 909-920.

54. Gungabissoon, R.A.; Jiang, C.J.; Drobak, B.K.; Maciver, S.K.; Hussey, P.J. Interaction of maize actin-depolymerising factor with actin and phosphoinositides and its inhibition of plant phospholipase C. Plant J. 1998, 16, 689-696.

55. Mondal, H.A.; Louis, J.; Archer, L.; Patel, M.; Nalam, V.J.; Sarowar, S.; Sivapalan, V.; Root, D.D.; Shah, J. Arabidopsis ACTIN-DEPOLYMERIZING FACTOR3 is required for controlling aphid feeding from the phloem. Plant Physiol. 2018, 176, 879-890.

56. Moran, P.J.; Thompson, G.A. Molecular responses to aphid feeding in Arabidopsis in relation to plant defense pathways. Plant Physiol. 2001, 125, 1074-1085.

57. Thaler, J.S.; Humphrey, P.T.; Whiteman, N.K. Evolution of jasmonate and salicylate signal crosstalk. Trends Plant Sci. 2012, 17, 260-270.

58. Cooper, W.R.; Goggin, F.L. Effects of jasmonate-induced defenses in tomato on the potato aphid, Macrosiphum euphorbiae. Entomol. Exp. Appl. 2005, 115, 107-115.

59. Sandoya, G.V.; de Oliveira Buanafina, M.M. Differential responses of Brachypodium distachyon genotypes to insect and fungal pathogens. Physiol. Mol. Plant Pathol. 2014, 85, 53-64.

60. Fan, K.T.; Wang, K.H.; Chang, W.H.; Yang, J.C.; Yeh, C.F.; Cheng, K.T.; Hung, S.C.; Chen, Y.R. Application of data-independent acquisition approach to study the proteome change from early to later phases of tomato pathogenesis responses. Int. J. Mol. Sci. 2019, 20, 863. 
61. Durrant, W.E.; Dong, X. Systemic Acquired Resistance. Annu. Rev. Phytopathol. 2004, 42, 185-209.

62. Wang, H.; Jiang, Y.P.; Yu, H.J.; Xia, X.J.; Shi, K.; Zhou, Y.H.; Yu, J.Q. Light quality affects incidence of powdery mildew, expression of defence-related genes and associated metabolism in cucumber plants. Eur. J. Plant Pathol. 2010, 127, 125-135.

63. Phuntumart, V.; Marro, P.; Métraux, J.P.; Sticher, L. A novel cucumber gene associated with systemic acquired resistance. Plant Sci. 2006, 171, 555-564.

64. Sabbagh, E.; Sabbagh, K.S.; Panjehkeh, N.; Bolok-Yazdi, H.R. Pythium aphanidermatum ile Bulaş1k Hıyarlarda Jasmonik Asitin Uyardığı Sistemik Dayanıklılık Jasmonic Acid Induced Systemic Resistance in Infected Cucumber by Pythium aphanidermatum. J. Agric. Sci. 2018, 24, 143-152.

65. Métraux, J.P. Systemic Acquired Resistance. Brenner's Encycl. Genet. 2013, 6, 627-629. [CrossRef]

66. Jin, W.; Horner, H.T.; Palmer, R.G.; Shoemaker, R.C. Analysis and mapping of gene families encoding $\beta-1,3$-glucanases of soybean. Genetics 1999, 153, 445-452.

67. Sabbagh, S.K.; Tanavar, L. Bio-fertilizer incidences on cucumber disease and defense reactions in response to Phytophthora melonis. Biol. Control Pests Plant Dis. 2019, 8, 1-15.

68. Liang, D.; Liu, M.; Hu, Q.; He, M.; Qi, X.; Xu, Q.; Zhou, F.; Chen, X. Identification of differentially expressed genes related to aphid resistance in cucumber (Cucumis sativus L.). Sci. Rep. 2015, 5, 9645.

69. Ali, J.G.; Agrawal, A.A. Specialist versus generalist insect herbivores and plant defense. Trends Plant Sci. 2012, 17, 293-302.

(C) 2020 by the authors. Licensee MDPI, Basel, Switzerland. This article is an open access article distributed under the terms and conditions of the Creative Commons Attribution (CC BY) license (http://creativecommons.org/licenses/by/4.0/). 